\title{
29. LATE MIOCENE TO PLEISTOCENE EVOLUTION OF CLIMATE IN AFRICA AND THE LOW-LATITUDE ATLANTIC: OVERVIEW OF LEG 108 RESULTS ${ }^{1}$
}

\author{
W. F. Ruddiman, ${ }^{2}$ M. Sarnthein,${ }^{3}$ J. Backman, ${ }^{4}$ J. G. Baldauf, ${ }^{5}$ W. Curry,${ }^{6}$ L. M. Dupont, ${ }^{7}$ T. Janecek, ${ }^{2}$ \\ E. M. Pokras,${ }^{2}$ M. E. Raymo, ${ }^{2}$ B. Stabell,${ }^{3,8}$ R. Stein, ${ }^{9}$ and R. Tiedemann ${ }^{3}$
}

\begin{abstract}
Two major goals of Leg 108 were to investigate late Cenozoic changes in (1) North African aridity and (2) atmospheric circulation over the equatorial Atlantic and Sahelian/Saharan Africa. Several high-resolution records from Ocean Drilling Program Leg 108 are pertinent to these problems. Dust fluxes from Africa to the Atlantic were low during the final $3 \mathrm{~m} . \mathrm{y}$. of the Miocene and then increased markedly during the Pliocene and Pleistocene. The increasing Pliocene-Pleistocene dust fluxes suggest major aridification of North Africa, possibly accompanied by an increase in the amplitude of aridity/humidity cycles. Other evidence from the northwest African margin (influxes of fluvial clay, terrestrial carbon, freshwater diatoms, and pollen) also suggests increasing aridity and larger oscillations during the Pliocene and Pleistocene, along with increased intensity of coastal trade winds.

Because prominent changes in long-term dust fluxes preceded Northern Hemisphere glaciation by $1.5 \mathrm{Ma}$, Northern Hemisphere ice sheets were not the major factor in the evolution of African climate, in agreement with late Pleistocene evidence at orbital time scales. The apparent synchroneity of several major long-term changes in climate over Africa and the equatorial Atlantic with changes in the Southern Ocean and South Atlantic suggests long-term linkage in the responses of these two regions, again similar to late Pleistocene linkages at orbital time scales.

The ultimate source of forcing of these changes at tectonic time scales is not fully resolved. The Messinian closing and abrupt reopening of the Mediterranean left no obvious imprint on signals of African dust flux. One plausible source of forcing is large-scale tectonic uplift, which occurred at unusually rapid rates during the latest Cenozoic in Southeast Asia (Tibet and the Himalayas), East Africa, and South America (the Andes and Altiplano). Modeling experiments show that uplift causes large-scale rearrangements of atmospheric circulation, including the strength and position of the upper tropospheric jet streams and the lower tropospheric high- and low-pressure cells that control surface winds and moisture balances.
\end{abstract}

\section{INTRODUCTION}

Two primary goals of Ocean Drilling Program (ODP) Leg 108 were to explore the late Cenozoic evolution of aridity over North Africa and to examine circulation changes over Africa and the low-latitude Atlantic. This paper examines those problems, based on Leg 108 shipboard and post-cruise studies.

The locations of Leg 108 sites are shown in Figure 1, along with several of the major climatic and vegetational belts in Africa relevant to the discussion. Modern-day seasonal changes in lower-level winds over Africa and the equatorial Atlantic are mapped in Figure 2. The positions of the summer and winter dust plumes over the Atlantic are shown in Figure 3 , along with their likely late Cenozoic source areas.

In this paper, we first review results from general circulation model experiments that indicate how several factors (insolation heating, glacial boundary conditions, $\mathrm{CO}_{2}$, and

\footnotetext{
${ }^{1}$ Ruddiman, W., Sarnthein, M., et al., 1989. Proc. ODP, Init. Results, 108: College Station, TX (Ocean Drilling Program).

2 Lamont-Doherty Geological Observatory, Palisades, NY 10964.

${ }^{3}$ Geologisch-Paläontologisches Institut und Museum, Universităt Kiel, Olshausenstrasse 40, D-2300 Kiel, Federal Republic of Germany.

${ }^{4}$ Department of Geology, University of Stockholm, S-10691 Stockholm, Sweden.

${ }^{5}$ Ocean Drilling Program, Texas A\&M University, 1000 Discovery Drive, College Station, TX 77840.

${ }^{6}$ Woods Hole Oceanographic Institution, Woods Hole, MA 02543.

${ }^{7}$ Institut für Palynologie und Quartärwissenschaften, Universität Göttingen, Wilhelm-Weber-Strasse 2, 3400 Göttingen, Federal Republic of Germany.

${ }^{8}$ Present mailing address: Department of Geology, University of Oslo, P. O. Box 1047, Blindern, N-0136 Oslo 3, Norway.

${ }^{9}$ Institut für Geowissenschaften und Lithospärenforschung, Universităt Giessen, Senckenbergstrasse 3, 6300 Giessen, Federal Republic of Germany.
}

tectonic uplift) may affect climate in Africa and the equatorial Atlantic. We also summarize published evidence (mainly from the late Quaternary) bearing on the model predictions. We then interpret Leg 108 results in light of the model predictions.

The main focus of this synthesis is the broad-scale evolution of climatic responses on tectonic time scales, longer than the primary orbital band $(20,000-100,000 \mathrm{yr})$. Although several paleoclimatic records reported in this volume were sampled at intervals that permit analysis at orbital time scales, detailed $\delta^{18} \mathrm{O}$ time series needed to establish accurate chronologies are not yet generally available.

\section{GENERAL CIRCULATION MODEL RESULTS AND RELEVANT PALEOCLIMATE DATA}

General circulation model (GCM) experiments have proven to be a valuable paleoclimatologic tool. One kind of experiment simulates atmospheric circulation at specific times in the past (Gates, 1976; Manabe and Hahn, 1977; Kutzbach and Guetter, 1986; Rind, 1987). Providing accurate boundary conditions at the earth's surface for this kind of study, however, requires enormous resources (CLIMAP, 1981) and becomes difficult for older geologic intervals due to dating uncertainties and the evolution of key biotic indicators.

A wider application of GCMs is for "sensitivity tests," in which boundary conditions at the earth's surface are altered one at a time relative to the modern ("control-case") run in order to isolate the unique impact of a specific factor on regional climate changes. The boundary conditions used in sensitivity tests need not be realistic portrayals of the earth's surface at any interval of geologic time; the purpose of these experiments is to assess the separate climatic influence of individual factors, not to recreate in full the conditions of the 


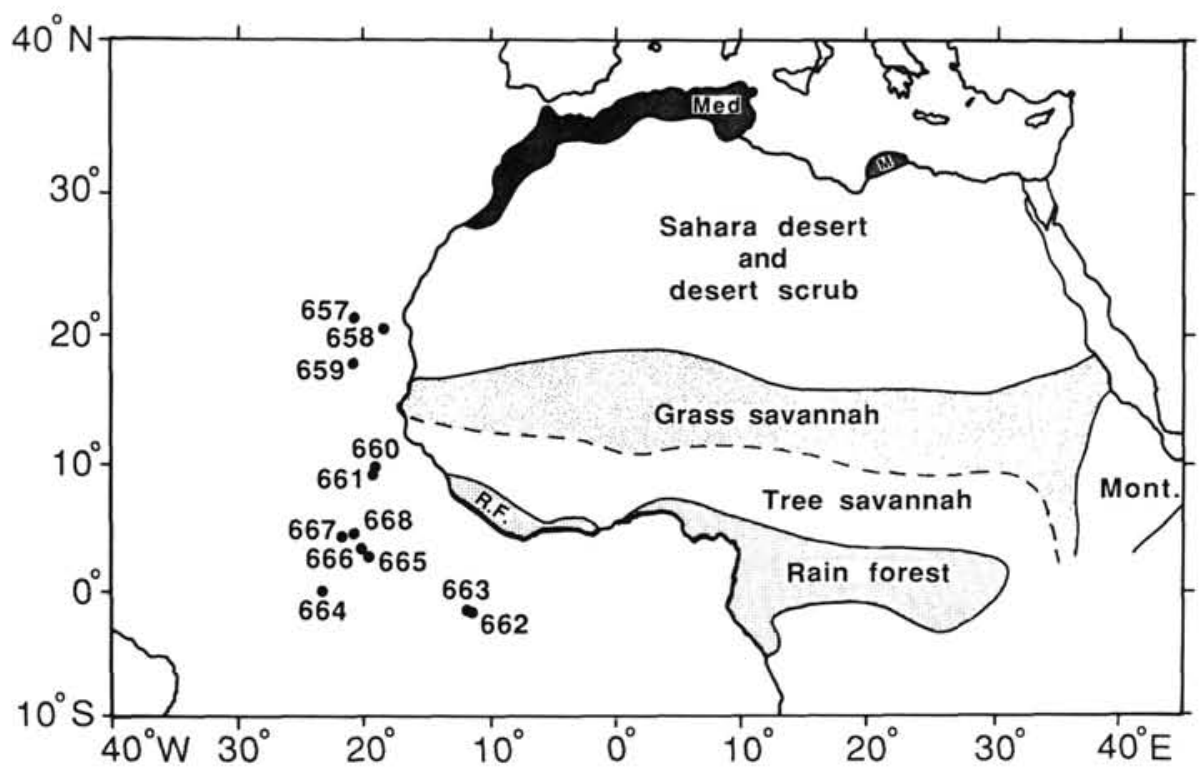

Figure 1. Location of Leg 108 sites and major vegetational and climatic belts in North Africa after Griffiths (1972). Small areas of Mediterranean vegetation are denoted by "Med" or "M"; rain forest, by "R.F."; and montaine vegetation, by "Mon."

past. These tests are vital, because the climate system is comprised of many interactive and closely coupled components. Major climatic changes often occur simultaneously in several areas, making it difficult to detect the critical causal interactions in the climate system. Sensitivity tests help to define those cause-and-effect relationships.

In this section, we used GCM studies, supplemented by published geologic evidence, to evaluate the impact of several kinds of changes in boundary conditions: (1) variations in seasonal insolation heating that influence monsoonal cycles of humidity and aridity; (2) changes in Northern Hemisphere glacial boundary conditions, including ice sheets, sea ice, and high-latitude sea-surface temperature (SST); (3) changes in atmospheric $\mathrm{CO}_{2}$ levels; (4) tectonic uplift of high plateaus and mountains, particularly Tibet; and (5) possible interactions among tropical lands, tropical oceans, and the Antarctic Ocean. Over the last $5 \mathrm{~m} . \mathrm{y}$., we can ignore climatic changes caused by plate motion; the Atlantic and Africa have moved northward by at most $1.5^{\circ}$ of latitude (Sclater et al., 1977).

We focused on the model-predicted climatic changes caused by each of these factors over Africa and the adjacent Atlantic Ocean. Because these models cannot simulate upwelling, the predictions of climatic change summarized here should be more accurate over the interior regions of the African continent and in mid-ocean regions, but they are less accurate over the equatorial divergence and coastal upwelling regions and over maritime regions of Africa.

\section{Changes in Seasonal Insolation Heating}

Kutzbach and others (Kutzbach, 1981; Kutzbach and StreetPerrott, 1985; Prell and Kutzbach, 1987; Kutzbach and Gallimore, 1988) have used results from diverse climate models to show that variable summer insolation heating is a major factor in cycles of aridity and humidity in northern Africa. Summer insolation maxima heat the continent and cause rising motion, resulting in increased monsoonal inflow of air from the Atlantic and wetter conditions in the Sahel and southern Sahara (Fig. 4). Summer insolation minima suppress these tendencies and cause aridity. The dominant periods of this insolation forcing lie in the precessional band (19,000-23,000 yr). In addition, decreased evaporation over land in winter because of reduced solar radiation also contributes to the positive annual moisture balance (Kutzbach and Street-Perrott, 1985).

Long-term geologic evidence consistent with these model predictions comes in part from ocean cores: (1) freshwater diatoms deflated from African lakes and blown to the Atlantic during periodic drying episodes (Pokras and Mix, 1985, 1987); (2) eastern Mediterranean sapropel deposits indicative of large injections of freshwater during monsoonal intervals (Rossignol-Strick, 1983); and (3) windblown pollen influxes along the Somali coast (Prell and Van Campo, 1986). In addition, there is broad support for the idea of insolation control of aridity from shorter-term changes during the last 20,000 yr in lake levels (Street and Grove, 1976; Street-Perrott and Harrison, 1984; Kutzbach and Street-Perrott, 1985) and in Niger River freshwater discharge volumes (Pastouret et al., 1978). Evidence of early Holocene humidity and late Holocene aridity along the northwestern African coast (PetitMaire, 1980) and in the hyperarid Egyptian Sahara (Ritchie et al., 1985) are also consistent with insolation forcing.

The history of lateral extension of sand deserts has been interpreted in the framework of an assumed glacial/interglacial forcing (Sarnthein, 1978), but the actual tempo of change is better matched to that of insolation forcing. Thus, insolation forcing influences the entire span of tropical North Africa from the Ethiopian Plateau in the east to the Niger basin and Atlantic coast, and from the Sahel in the south to the central Sahara in the north. The only discrepancy between insolation forcing and the observed responses recorded in ${ }^{14} \mathrm{C}$-dated sequences on Africa is the delayed onset of the most recent monsoon interval until $12,500 \mathrm{yr}$ ago, several thousand years after rising summer insolation values would predict.

\section{Glacial Boundary Conditions: Ice Sheets and SST}

We consider here the combined effects of changes in Northern Hemisphere ice sheets and SST in the middle and high latitudes of the North Atlantic. Geologic evidence (Ruddiman and McIntyre, 1984; Ruddiman et al., 1986) and GCM 

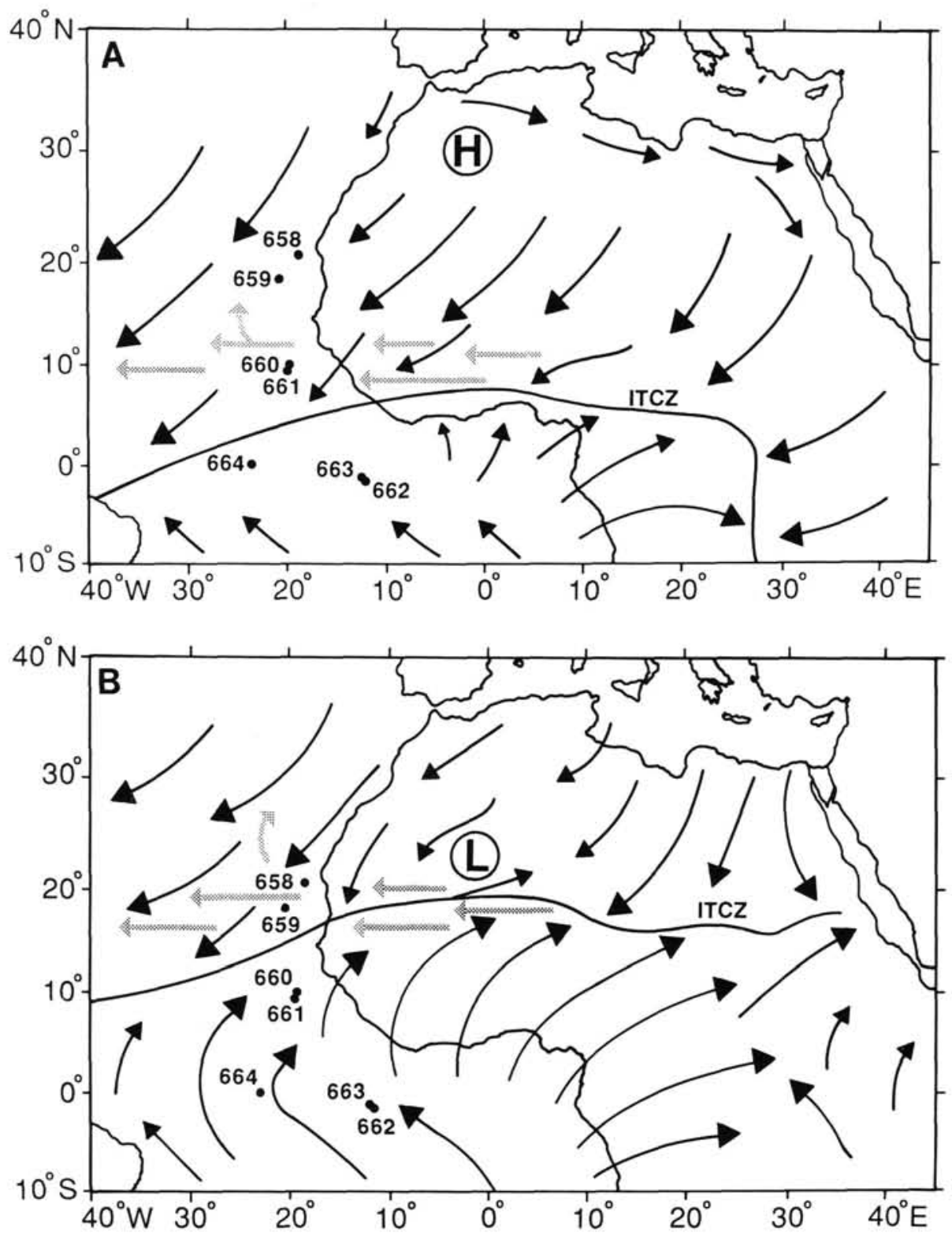

Figure 2. Average low-level wind circulation and Intertropical Convergence (ITCZ) position in northern winter (A) and summer (B) after Griffiths (1972). Thin arrows show surface winds. Large stippled arrows show the easterly flow in the mid-level African Easterly Jet (AEJ) and the Saharan Air Layer, which carry large quantities of eolian dust (Sarnthein et al., 1981). Also shown are the positions of Leg 108 sites that contain the terrigenous influx signals discussed in the text.

sensitivity tests (Manabe and Broccoli, 1985) show that these components of the climate system were tightly coupled during the Pleistocene, and so we can evaluate them as a single unit. Model sensitivity tests by Rind (1987) suggest that glacial-age North Atlantic SST, rather than ice sheets, may be the main factor affecting temperature, precipitation, and low-level winds in North Africa. Results from Rind et al. (1986) indicate that SST changes in the Atlantic north of $25^{\circ} \mathrm{N}$ explain much of the winter and part of the summer temperature response over North Africa.

The combined climatic effects of ice sheets and highlatitude SST decrease toward the equator (Manabe and Broccoli, 1985; Broccoli and Manabe, 1987). Sensitivity tests with glacial-maximum ice sheets inserted into a GCM coupled to a mixed-layer ocean model show mean annual and seasonal temperature decreases of $2^{\circ} \mathrm{C}-4^{\circ} \mathrm{C}$ over northwestern Africa, decreasing to $1^{\circ} \mathrm{C}$ or $2^{\circ} \mathrm{C}$ in central Africa (Broccoli and Manabe, 1987). The same model predicts SST changes of $1^{\circ} \mathrm{C}-2^{\circ} \mathrm{C}$ in summer and winter over the Atlantic between $0^{\circ} \mathrm{N}$ and $30^{\circ} \mathrm{N}$ (Manabe and Broccoli, 1985). Rind (1987) found that the combined glacial ice and SST changes predicted widespread summer and winter cooling of $1^{\circ} \mathrm{C}-5^{\circ} \mathrm{C}$ in northern Africa. We summarize these results in Figure 5. For the smaller glaciations earlier in the Pleistocene and late Pliocene, these simulated changes would have to be scaled down by half or more. 


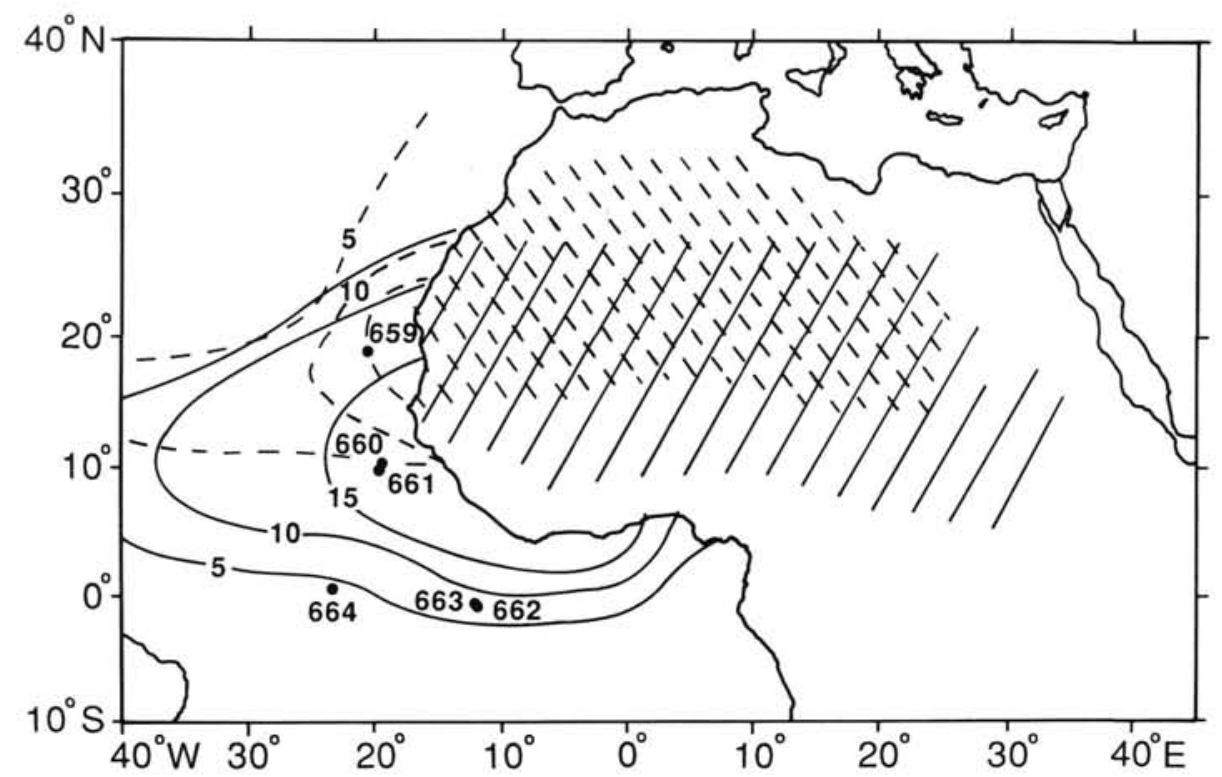

Figure 3. Locations of dust plumes as detected by haze frequency contours in northern summer (dashed lines) and northern winter (solid lines) after McDonald (1938). Spring and autumn plumes occupy intermediate positions between these extremes. The approximate extent of North African source regions for dust plumes are shown for northern summer (dashed pattern) and northern winter (solid pattern). Based on data in Dubief (1979), Kalu (1979), Glaccum and Prospero (1980), Prospero (1981), and D'Almeida (1986). Also shown are the positions of Leg 108 sites with long-term terrigenous influx records.

The unique effects of ice sheets and high-latitude SST on moisture balances and low-level winds over Africa and the adjacent Atlantic are as yet unclear. The only published sensitivity test results (Manabe and Broccoli, 1985) found increases in precipitation in tropical Africa and decreases in northern and western Africa between $15^{\circ} \mathrm{N}$ and $30^{\circ} \mathrm{N}$ to be statistically insignificant. Simulations based on full recon- structions of the last glacial maximum also yield inconclusive or partially contradictory changes in precipitation and lowlevel winds compared with modern conditions. In addition, warm tropical SST values assigned by CLIMAP (1981) determine much of the wind strength and moisture fluxes at low latitudes by setting land-sea temperature and pressure gradients.

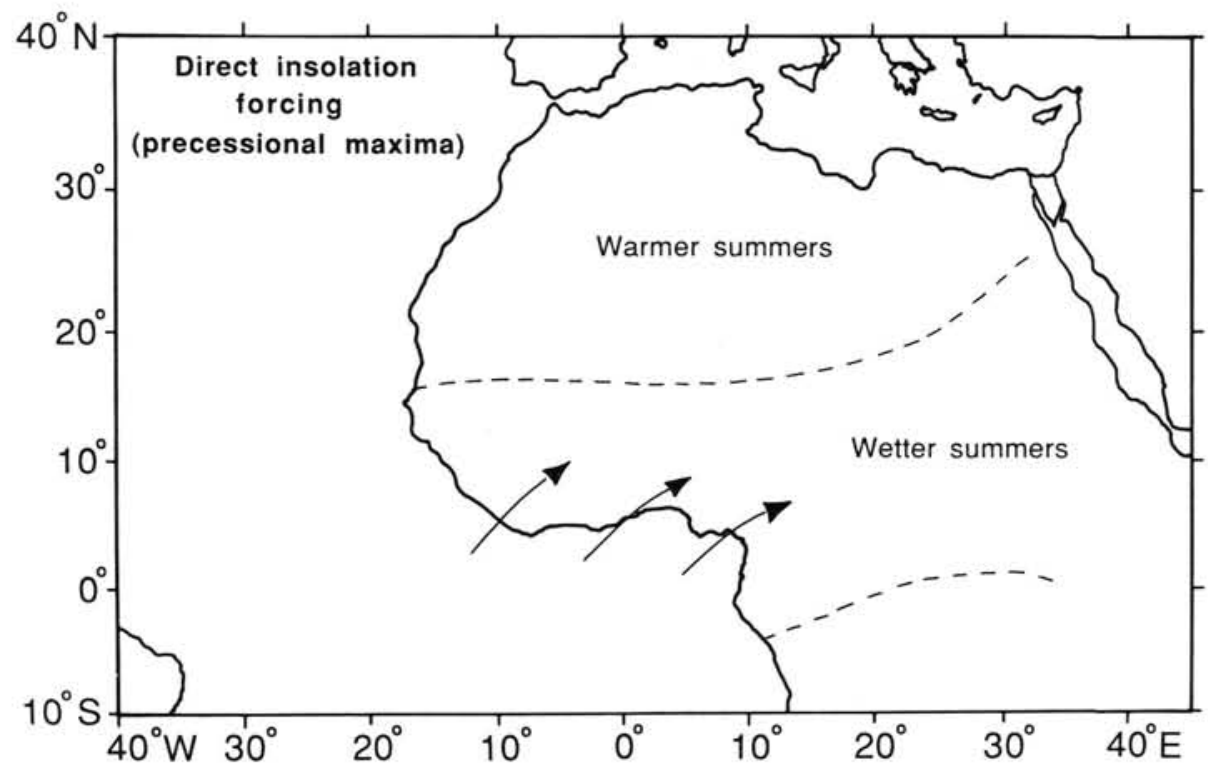

Figure 4. Schematic based on Kutzbach (1981) showing the major effects of summer insolation on North Africa at precessional periods $(19,000-23,000 \mathrm{yr})$. Heating of central and northern Sahara during precessional maxima causes summer inflow of monsoonal winds from the Atlantic. Precessional minima would have the opposite effects: cooler summers in the Sahara, and drier summers in the Sahel and tropics to the south. 


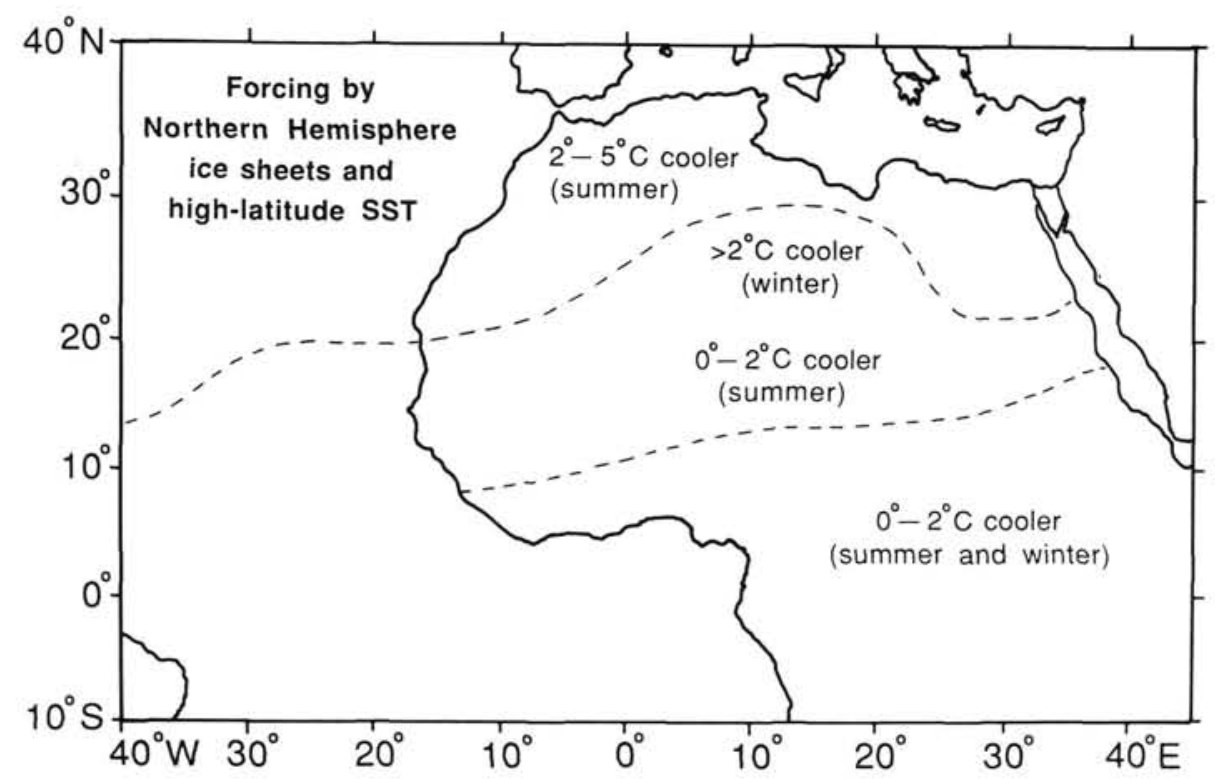

Figure 5. Schematic of the effects of Northern Hemisphere ice sheets (and associated changes in sea-surface temperature in the high-latitude North Atlantic) on climate in North Africa. The major effect is a cooling in both seasons, with amplitudes largest in the north and northwest. Based on sources described in text.

For glacial-maximum summers in the Northern Hemisphere, Gates (1976) found that the Intertropical Convergence Zone (ITCZ) moved south by $4^{\circ} \mathrm{C}$ relative to today, with precipitation higher to the south and lower to the north. However, Manabe and Hahn (1977) found a weaker July monsoonal flux into western North Africa at all latitudes, and little change in low-level winds. Kutzbach and Guetter (1986) and Rind (1987) found little change in Hadley cell circulation and ITCZ position over Africa and near the coast, although Rind noted stronger trade winds over the central Atlantic north of $25^{\circ} \mathrm{N}$. Both Kutzbach and Guetter (1986) and Rind (1987) found slightly lower precipitation in western tropica. Africa, and higher values to the east near warm Indian Ocean SST values.

For glacial-maximum winters in the Northern Hemisphere, Rind (1987) found stronger trade winds over the central Atlantic north of about $15^{\circ} \mathrm{N}$, but again little change over the African coast or equatorial Atlantic. Kutzbach and Guetter (1986) also found little change in strength or position of winter trade winds. Both Kutzbach and Guetter (1986) and Rind (1987) found slight (statistically insignificant) decreases in soil moisture in western Africa and higher values to the east, the latter again caused by warmth in the Indian Ocean. In summary, modeling experiments in general do not suggest major wind changes over or near Africa because of glaciation. In contrast, geologic comparisons of the last glacial maximum and the Holocene suggest several changes in moisture balance and in low-level and mid-level winds that have been widely linked to Northern Hemisphere glaciation. This has reinforced the view (Butzer, 1957; Butzer et al., 1972) that glaciations are intervals of aridity in Africa rather than "pluvials."' On closer inspection, however, most of this evidence is more consistent with insolation control of aridity.

Sarnthein (1978) noted a major increase in the extent of active sand dunes at the last glaciation $(18,000 \mathrm{yr}$ ago) compared with the climatic optimum $(6,000 \mathrm{yr}$ ago), implying a strong glacial control on aridity. $\mathrm{He}$ also noted, however, that the strong drying during the last $5000 \mathrm{yr}$ is not explained by ice sheets. As noted above, it is in fact more consistent with insolation forcing. The same issue arises in pollen and other trends from the late Quaternary, which show deglacial humidity and late Holocene aridity (e.g., Caratini et al., 1979; Rossignol-Strick and Duzer, 1979; Lezine, 1988; Hooghiemstra, 1988) rather than glacial aridity and Holocene humidity.

The limited duration of dated continental records $(20,000-30,000 \mathrm{yr})$ makes it difficult to separate aridity changes caused by ice sheets from those directly forced by precessional insolation. One longer-term suggestion of significant ice-sheet control of aridity comes from late Pleistocene records of phytoliths (siliceous bodies found in grass cuticles) from eastern Atlantic sediments (Pokras and Mix, 1985); these trends suggest southward shifts of the savanna grass vegetation during glacial isotopic stages. Such a shift also occurs, however, during the late Holocene (Maley, 1983; Lezine, 1988).

Other geologic data have also been interpreted as indicating changes in trade-wind strength and ITCZ position at a glacial tempo. Quartz grain-size changes in Atlantic sediments of last glacial age have been interpreted as evidence for stronger summer trade winds (Parkin and Shackleton, 1973) and weaker winter trade winds (Parkin and Padgham, 1975). Sarnthein et al. (1981) inferred stronger summer trade winds during the last glacial maximum in cores along the northwestern African coast, but they noted that the inferred increase in trade-wind strength in the late Holocene does not follow a glacial/interglacial tempo. Intensified trade winds in northern spring during glacial isotopic stage 2 have been inferred from southward-displaced pine-pollen contours (Hooghiemstra et al., 1987; Hooghiemstra, 1988).

There is reason for considerable caution in interpreting grain-size data from the African continental margin. Changes in distance to source areas and in thickness of the dust-bearing air layer can affect grain-size distributions and complicate interpretations of past wind velocities. In addition, core-top data clearly show evidence of large-scale downslope "grainby-grain" redistribution of hemipelagic sediment along the 
African continental margin (Seibold, 1980). With glacial lowering of the sea level toward the edge of the continental shelf, this factor could become even more of a problem, with the possibility that some grain-size responses at the glacial/interglacial tempo are related to sea level rather than to the climate in Africa.

Possible trade-wind control of upwelling along the African coast north of $18^{\circ} \mathrm{N}$ at tempos dictated by ice sheets is suggested by the strong similarity between organic carbon flux rates and $\delta^{18} \mathrm{O}$ records (Müller and Suess, 1979; Stein, 1985a). Seaward dislocation of the centers of the upwelling cells because of glacial sea-level lowering is, however, an alternative explanation of such trends (Müller and Suess, 1979). Mix (in press) found that transfer-function estimates of last glacial productivity farther from the African coastal margin were slightly lower than modern values, with changes in the foraminiferal faunas apparently explained by stronger advection in the Canary Current (see also Thiede, 1977; Sarnthein, 1982; Sarnthein et al., 1988).

Other factors such as variable river runoff (Diester-Haass, 1983; Stein, 1985a), lateral redistribution of sediment (including carbon) from shallow to deep areas of the African continental margin (Thiede, 1977), and changes in nutrient content of the upwelled waters (Labracherie, 1980; Stein, 1985a) may also complicate inferences of trade-wind strength from productivity indicators on the African margin. In short, although several studies have postulated a glacial/interglacial tempo for changes in trade-wind strength, none provide unambiguous evidence that this is the controlling factor.

The interpretation of past ITCZ positions from geological evidence has been somewhat controversial. Nicholson and Flohn (1980) proposed southward displacements of the ITCZ during glacial summers and winters, but Gardner and Hays (1976) inferred no significant change in the northern winter position. Sarnthein et al. (1981) and Hooghiemstra (1988) argued for no significant change in the northern summer positions. The balance of opinion thus favors little change in the ITCZ in either season because of ice sheets.

In summary, although ice sheets were thought for several decades to affect or control moisture balances in Africa, more recent work indicates that the tempo of aridity across most of Africa is more closely linked to precessional insolation forcing. A glacial/interglacial tempo may be present along the northwestern African margin (Pokras and Mix, 1985), where model results show that ice-sheet forcing is strongest (Fig. 5).

\section{Glacial/Interglacial Changes in Atmospheric $\mathrm{CO}_{2}$}

Decreasing atmospheric $\mathrm{CO}_{2}$ content is considered to be a factor in the long-term climate cooling since the Cretaceous (Barron and Washington, 1985), with the fastest $\mathrm{CO}_{2}$ decreases due to slowing of seafloor subduction placed in the Late Cretaceous and early Cenozoic (Berner et al., 1983). Because the full history of $\mathrm{CO}_{2}$ change in the middle and late Cenozoic is not known, we review here only changes during the late Pleistocene. Large, orbital-scale changes in atmospheric $\mathrm{CO}_{2}$ during the last $150,000 \mathrm{yr}$ have been detected in ice cores (Barnola et al., 1987); these may be either the cause or the result of changes in Northern Hemisphere ice volume. We review here the climatic effects of lowered $\mathrm{CO}_{2}$ during the last glacial maximum.

Sensitivity tests with a GCM coupled to a mixed-layer ocean model (Broccoli and Manabe, 1987) suggest that lower $\mathrm{CO}_{2}$ values at the last glacial maximum caused mean annual coolings centered in the same region of northwestern Africa as those caused by the ice sheets and northern oceans, but at smaller amplitudes (Fig. 6). Over the Atlantic, the predicted annual temperature decrease was less than $1^{\circ} \mathrm{C}$, except along the northwestern coast of Africa. These changes are all consistent in pattern and (scaled) magnitude with several GCM experiments with doubled $\mathrm{CO}_{2}$ (Schlesinger and Mitchell, 1987). Model predictions of $\mathrm{CO}_{2}$-induced changes in moisture balance in Africa show very small changes in winter and inconsistent model-to-model variations in summer (Schlesinger and Mitchell, 1987).

\section{Tectonic Uplift}

Ruddiman et al. (in press) summarized the evidence for large-scale (kilometer) uplift during the late Cenozoic in the two regions of highest terrain in the Northern Hemisphere: the Tibetan Plateau and the American Southwest. These regions have attained half or more of their present elevation within the last 5-10 m.y. The GCM sensitivity tests were run (Kutzbach et al., in press) with all land elevations reduced to sea level (the "no-mountain" case) and with Tibet and western North America lowered by half (the "half-mountain" case). Statistically significant changes in atmospheric circulation over Africa and the equatorial Atlantic caused by uplift are summarized schematically in Figure 7.

Simulated changes in land temperature caused by uplift are modest (Fig. 7A). East Africa cools in both seasons because of lapse-rate effects on the uplifted terrain. Cooling is also observed in the northern Sahara and in northeastern Africa in both seasons. The uplift experiment simulates a large decrease in summer precipitation over eastern and northernmost Africa (Fig. 7A). This occurs in part because of a strengthened counterclockwise flow of air around the low-pressure system over India and Southeast Asia; as the Tibetan Plateau becomes a stronger heat source in summer, this low deepens. Near Africa, the strengthened counterclockwise flow is northeasterly and delivers dry air from the Asian interior.

Moisture is also reduced in eastern Africa and over the Mediterranean in summer by the increased subsidence of dry air, whereas a rising motion in tropical Africa causes more summer precipitation along the Ivory Coast and in the Sahel (Fig. 7A). These simulated changes in precipitation strengthen the already existing north-south moisture gradient in Sahelian Africa. They occur in association with a strengthening of the summer Tropical Easterly Jet (TEJ) over Africa (Fig. 7B). Without uplift, a slow diffuse easterly flow crosses Africa, but the $10-\mathrm{m} / \mathrm{s}$ (mean) contour does not occur over Africa; with half uplift, the $10-\mathrm{m} / \mathrm{s}$ contour extends westward across half of Africa; with full uplift, it projects almost to the Atlantic at $14^{\circ} \mathrm{N}$. Flohn and Nicholson (1980) and Hastenrath (1985) previously suggested that the existence of the TEJ over North Africa is linked to the elevated terrain in Tibet, and the model results (Fig. 7B) support this idea.

Flohn and Nicholson (1980) also suggested that strengthening of the TEJ would lead to a rising motion and more precipitation over tropical Africa and to a subsiding motion and less precipitation over subtropical northern Africa, as part of a vertical circulation pattern in the region of the strengthened jet-stream maximum over Africa. Jet-stream maxima are regions of locally accelerated flow at jet-stream altitudes. Downstream from the core of the jet maximum in the "exit" region of decelerating flow, rising motion (and thus moist climate) occurs to the left (south) of the decelerating jet axis, paired with subsiding motion (and thus dry climate) to the right (north) of the axis (Hastenrath, 1985; Lamb et al., 1986). This pattern (wet tropics, dry subtropics) should enhance the basic vertical motions already established by the Hadley cell over North Africa during the late Cenozoic by Africa's low-latitude position in plate-motion reconstructions (Barron et al., 1981). 


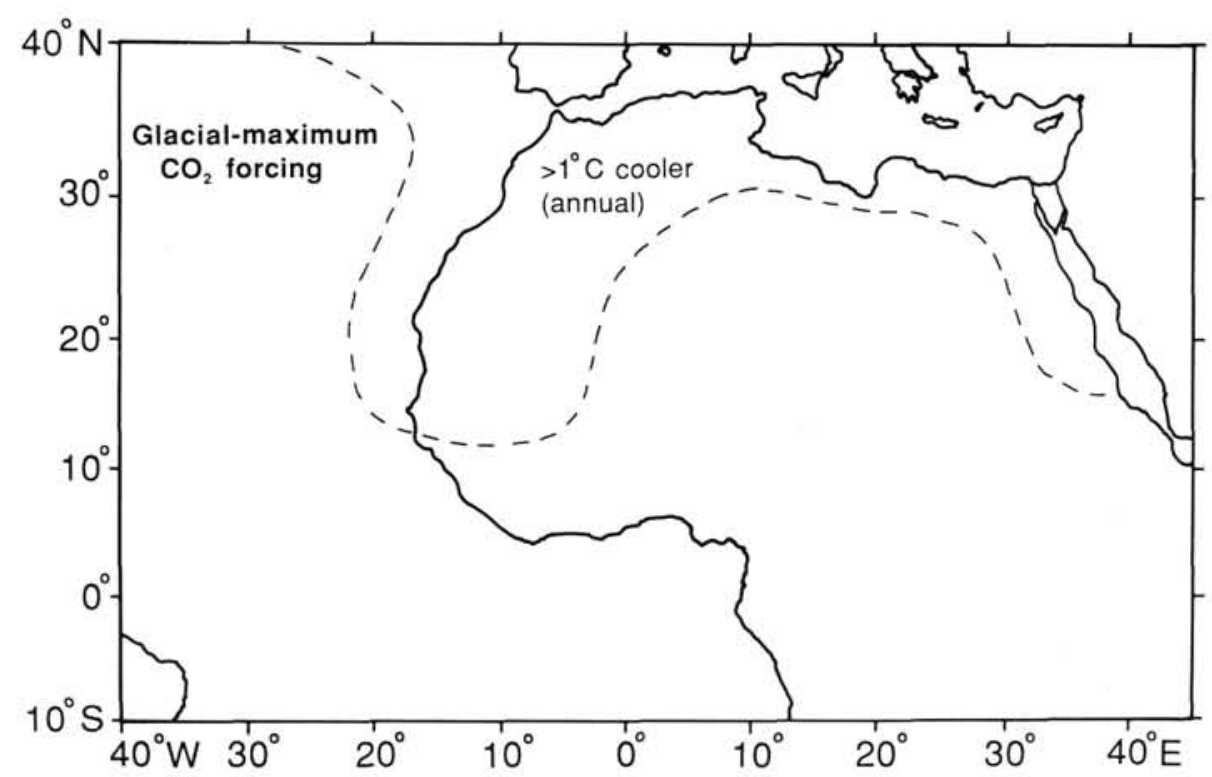

Figure 6. Schematic of the effects of lowered $\mathrm{CO}_{2}$ during glacial maxima on climate in North Africa. The major effect is a cooling in both seasons, with amplitudes largest in the north and northwest. Based on sources described in the text.

Model results directly support this prediction in western tropical Africa, where enhanced rising motion causes increased precipitation, and over both the Mediterranean and northwesternmost Africa, where increased subsidence causes drier summers (Fig. 7A). The model disagrees with the prediction of drier summers in the central and northern Sahara $\left(15^{\circ} \mathrm{N}-30^{\circ} \mathrm{N}\right)$, where precipitation is simulated either to increase slightly or to change insignificantly. Although this disagreement may indicate that the Flohn-Nicholson hypothesis is incorrect in calling for drying in the central Sahara, the modern circulation (vertical circulation) associated with the TEJ does imply that a stronger TEJ should strengthen summer subsidence and drying over the central and northern Sahara. Given the difficulties most GCMs have in reproducing modern patterns of precipitation and evaporation, it is plausible to interpret this difference as a consequence of a model problem, rather than as an argument against the Flohn-Nicholson hypothesis.

In summary, the uplift simulation confirms that uplift of the Tibetan Plateau causes the development of the TEJ in summer over Africa (Fig. 7B), along with rising motion and increased rainfall in the tropics and sinking motion and decreased rainfall in the subtropics (Fig. 7A). The Flohn-Nicholson hypothesis further suggests that these processes should lead to drier climates in central Saharan Africa.

Ruddiman and Kutzbach (in press) noted many lines of evidence consistent with the uplift experiment simulations at middle and high latitudes. For example, vegetation in southwestern Asia near the Black Sea changed from forest to steppe gradually over the last $10 \mathrm{~m} . y$. (Traverse, 1982). In addition, elements of the typical "Mediterranean" flora first became abundant in that region between 3.2 and $2.8 \mathrm{Ma}$, as a consequence of the onset of drier summers (Suc, 1984). Marine stable isotope and benthic faunal data suggest that the balance between precipitation and evaporation in the Mediterranean basin became more negative (drier) in the last 5 m.y. (Thunell et al., 1987). Cerling et al. (1986) interpreted the change from $\mathrm{C} 3$ to $\mathrm{C} 4$ vegetation as evidence of increasing aridity in eastern Africa over the last 2 m.y.
Other important changes not shown in Figure 7 also occurred in the uplift simulation (Kutzbach et al., in press; Ruddiman et al., in press). In winter, uplift caused increased precipitation over the eastern Mediterranean, which should also have enhanced the development of the Mediterranean (summer-dry, winter-wet) climate and vegetation. In the annual mean, however, summer drying dominates this region.

In the northeastern Atlantic and along the northwestern African coast, the model simulates a marked increase in subsidence in the subtropical high-pressure cell with uplift (Kutzbach et al., in press). This results in a strengthening of summer trade winds north of $20^{\circ} \mathrm{N}$ along the African margin, including a reversal from westerly to northeasterly flow between latitudes $30^{\circ} \mathrm{N}$ and $40^{\circ} \mathrm{N}$. These changes in wind flow cause a drier summer climate along the northwestern African margin at all latitudes north of $15^{\circ} \mathrm{N}$ (Ruddiman and Kutzbach, in press), although drying in this region is not significant at the 99\% confidence level. Axelrod and Raven (1978) previously inferred, but did not explain, an increase in the strength of the summer subtropical high in this region during the Neogene. The uplift experiment did not simulate perceptible changes in winter trade winds along the African margin.

Major uplift has also occurred in the Southern Hemisphere in the Pliocene and Pleistocene. The High Andes and Altiplano have achieved much of their current elevation in the late Miocene, Pliocene, and Pleistocene (Berry, 1938; Benjamin et al., 1987), and the elevated terrain of eastern and southeastern Africa has also risen dramatically during that interval (King, 1962). The climatic effects of this Southern Hemisphere uplift have not yet been systematically analyzed, but they are likely to include changes in upper and lower atmospheric circulation of the kind already observed in the Northern Hemisphere. Some of these changes may well have impacted climate as far north as the equator and into low latitudes of the Northern Hemisphere.

\section{Low-Latitude SST and Circumantarctic Changes}

Another source of forcing of low-latitude climate involves interactions among three components of the climate system: 

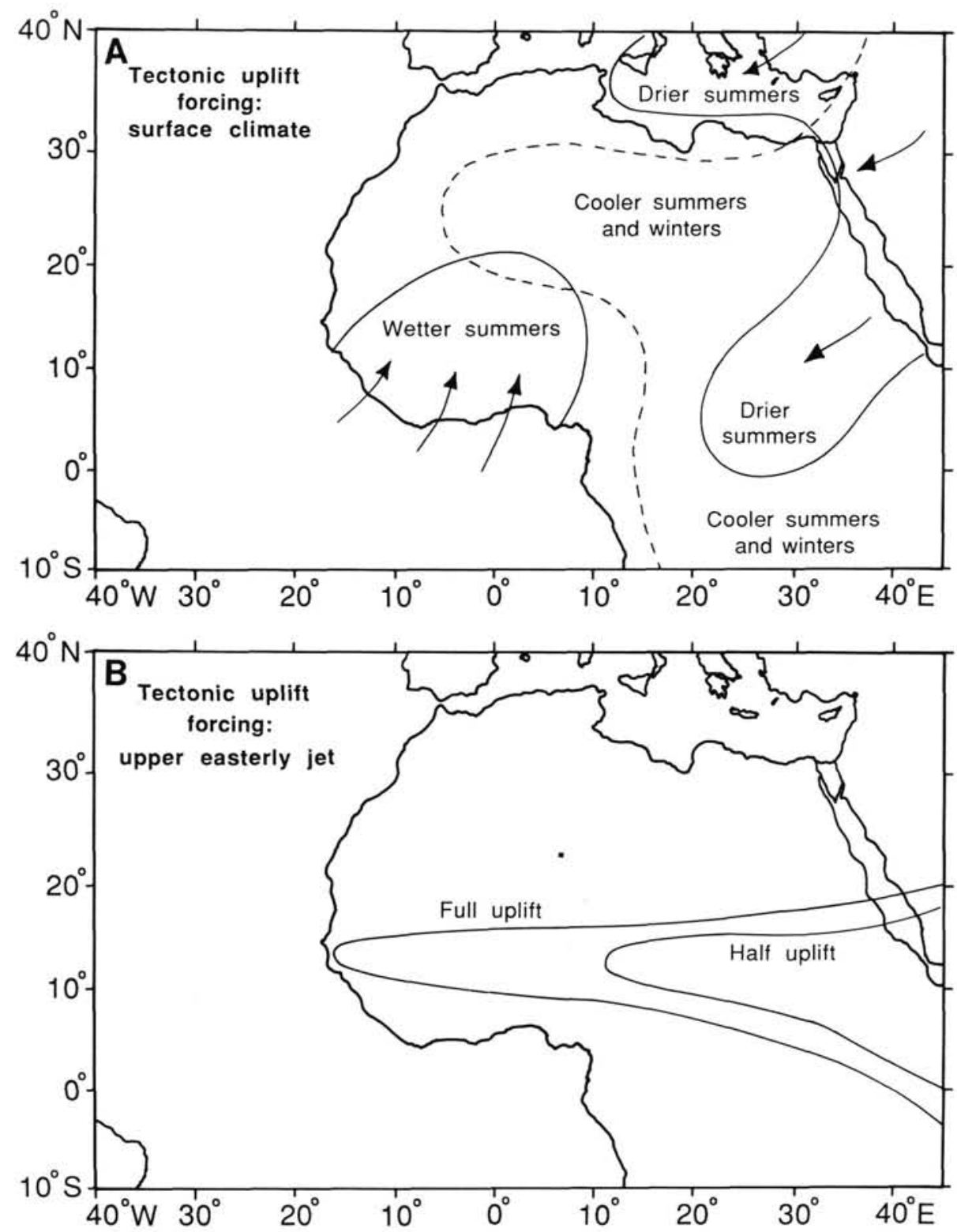

Figure 7. Effects of tectonic uplift on African climate. A. Drier summers in eastern North Africa and over the Mediterranean result from stronger northeasterly winds caused by increased cyclonic monsoonal circulation around Tibet, as well as increased subsidence. Cooler summers and winters over East Africa result from lapse-rate effects on uplifted terrain. Wetter summers in tropical western Africa and the western Sahel result from increased rising motion and monsoonal inflow. Only highly significant changes are shown. B. Tropical Easterly Jet (TEJ) from upper troposphere, as defined here by the $10 \mathrm{~m} / \mathrm{s}$ mean contour. The TEJ does not exist over Africa in the absence of the Tibetan Plateau, but the contour extends halfway across Africa for half uplift and completely across Africa for full uplift.

tropical land, tropical ocean temperatures, and circumantarctic sea ice and temperatures. Because these components appear to be highly interactive, it is difficult to disentangle cause-and-effect linkages and detect the "ultimate" source of forcing among the three.

As summarized earlier, both modeling and data support the idea of precessional insolation heating of tropical land masses as a cause of monsoon flow into Sahelian Africa. A key aspect of the stronger monsoon flow is the increased thermal contrast between the heated land mass and the still-cool ocean. If these changes, initiated by heating of the land, redirect atmospheric circulation over the nearby ocean, they could also be an important factor in controlling low-latitude SST in the Atlantic (Mix et al., 1986; McIntyre et al., 1989).

On the other hand, the opposite sense of land-sea linkage has also been hypothesized. Several studies suggest that cooler equatorial Atlantic SST values in summer significantly reduce the monsoonal transport of moisture into Sahelian Africa (Maley, 1973; Rognon and Williams, 1977; Sarnthein, 1978; Nicholson and Flohn, 1980; Sarnthein et al., 1982). In 
this view, the "first cause" of changes in the land-sea thermal contrast lies in the ocean, not on land. Tiedemann et al. (this vol.) further suggested that variations in equatorial Atlantic SST at the precessional cycle noted by several studies (Gardner and Hays, 1976; McIntyre et al., 1989; Karlin et al., this vol.; Pflaumann et al., in press) have forced cycles of Sahelian aridity at the same periodicity.

The only existing GCM sensitivity test of this idea has shown the opposite result: warm August SST anomalies between $5^{\circ} \mathrm{S}$ and $10^{\circ} \mathrm{N}$ in the Atlantic and the Gulf of Guinea produce drier conditions in the Sahel (Palmer, 1986). This test was based on SST anomalies of $<1^{\circ} \mathrm{C}$, comparable to modern interannual variations, but much smaller than the glacial/interglacial changes. This model prediction agrees with the relationship detected from correlations between SST and Sahelian aridity at interannual time scales (Lamb et al., 1986), and both results caution against viewing a cool equatorial ocean as the cause of a dry Sahel. A correlation does exist, however, between (cool) SST in the spring season and Sahelian drying in the following summer. Evidence from box modeling also suggests a link between the water content of air over the Atlantic and precipitation in the Sahel (Tetzlaff et al., in press).

Another consideration in calling on the equatorial ocean as the initiator of the orbital-scale changes is the small amplitude of the direct response of the ocean to insolation forcing (Schneider and Thompson, 1979; Kutzbach and Gallimore, 1988). The mixed layer of the ocean has a much larger thermal inertia than the land, and it greatly attenuates the effects of insolation by mixing the changes through $50-100 \mathrm{~m}$ of water. In addition, changes in insolation are seasonally opposed, so that insolation excesses in summer are largely counteracted by insolation deficiencies in winter. As a result, the direct response of the equatorial ocean to insolation only results in changes of tenths of a degree centigrade.

In contrast, the temperature of the mixed layer of the equatorial ocean has varied by as much as $7^{\circ} \mathrm{C}-8^{\circ} \mathrm{C}$ at the precessional period (CLIMAP, 1981; Gardner and Hays, 1976; Pflaumann, 1986, in press; McIntyre et al., 1989). This large a signal must reflect a response to orbital forcing registered elsewhere in the climate system and then imposed on the equatorial Atlantic. Aside from the possibility of insolation heating of tropical land masses, it has also been proposed that equatorial Atlantic changes may be driven by changes in circulation imposed from the Southern Ocean (Gardner and Hays, 1976; Mix et al., 1986; McIntyre et al., 1989). Forcing from the Southern Hemisphere makes sense from an interannual viewpoint because the Atlantic Ocean as far north as $5^{\circ} \mathrm{N}$ lies in the Southern Hemisphere thermal regime (cooler SST in August than in February). In addition, there are coherent, in-phase responses between the dominant 23,000-yr SST response at the equator over the last $200,000 \mathrm{yr}$ and a strong precessional component of SST change in the subantarctic (McIntyre et al., 1989).

Whatever the origin of the land-sea thermal contrast along the Guinean coast of Africa, this gradient has an important effect on circulation over Sahelian Africa. The strength of the mid-level African Easterly Jet (AEJ) is directly linked to the thermal gradient between warm air over the Sahara desert and cooler maritime air to the south over the Atlantic (Burpee, 1972). The AEJ, and the associated easterly flow in the Saharan Air Layer (Fig. 2), carry most of the northern summer load of Saharan and Sahelian dust at levels between 1.5 and $6 \mathrm{~km}$ (Carlson and Prospero, 1972; Prospero and Carlson, 1972).

\section{Summary}

Figures 4 through 7 summarize the likely regional impacts of several different kinds of forcing over Africa and the tropical Atlantic. Variations in insolation cause rhythmic (precessional) changes in the heating of Saharan Africa and in moisture fluxes into the western and central Sahel. The cooling influences of Northern Hemisphere ice sheets, of SST at middle and high northern latitudes, and of atmospheric $\mathrm{CO}_{2}$ are largest in northern Africa and may extend southward along the western African margin; however, ice-sheet effects on African aridity appear to be considerably less important than direct insolation forcing. Tectonic uplift predicts cooling and drying in eastern Africa, drying in the Mediterranean region and along the northwest African margin, and wetter conditions in the tropics and western Sahel. Changes in Antarctica may also have influenced low-latitude climate, particularly in the equatorial Atlantic.

Still other changes may have affected circulation in the tropics during the last $8 \mathrm{~m} . \mathrm{y}$. Closing and then reopening communication between the Mediterranean and the Atlantic for about $1 \mathrm{~m} . \mathrm{y}$. in the latest Miocene and earliest Pliocene (Ryan, Hsü, et al., 1973) should have had some effect on moisture balances in the Mediterranean region, although this has not been tested with GCM experiments. Closing the Panamanian Isthmus (Keigwin, 1982) in the Pliocene could also have been important in affecting circulation in the Atlantic and around its margins. Experiments are underway to test this idea (Maier-Reimer et al., 1989).

\section{LONG-TERM CLIMATE CHANGES: CONCEPTUAL MODELS AND OBSERVED TRENDS}

For three of the climatic controls just discussed, we show a schematic representation in Figure 8 of the expected evolution of the patterns of climatic response over the last 5 m.y. We also show an example of the possible response to a combination of controls.

Curve A shows a hypothetical response to precessional insolation forcing via heating of land masses and modulation of the monsoon. We indicate schematically the modulation of the precessional signal by eccentricity at periods near 100,000 and 413,000 yr (Milankovitch, 1941; Berger, 1978). Direct insolation forcing maintains a constant long-term mean value (Fig. 8).

Curve B portrays oscillatory responses to control by Northern Hemisphere ice sheets and associated glacial boundary conditions. The inception of significant Northern Hemisphere ice sheets was originally dated to $2.4 \mathrm{Ma}$ (Shackleton et al., 1984), but later work has shown that the change occurred over the interval from 2.65 to $2.4 \mathrm{Ma}$ (Keigwin, 1986; Raymo et al., 1989; Curry and Miller, this vol.; Sarnthein and Tiedemann, this vol.). Smaller rhythmic $\delta^{18} \mathrm{O}$ fluctuations began as early as 2.9 Ma in deep waters (Keigwin, 1986; Raymo et al., 1989 ) and even earlier in intermediate waters (Sarnthein and Tiedemann, this vol.), but ice-rafted debris did not reach the open North Atlantic Ocean.

Middle Pliocene "events" (apparently not rhythmic) in the $\delta^{18} \mathrm{O}$ record (Keigwin, 1986) probably represent changes in deep-ocean temperature or in antarctic ice volume, rather than in Northern Hemisphere ice volume. Following the glacial onset between 2.65 and $2.4 \mathrm{Ma}$, ice-volume fluctuations of moderate size then occurred during the $1.7 \mathrm{~m} . \mathrm{y}$. of the Matuyama Chron mainly at the 41,000 -yr period of orbital tilt (Ruddiman and Raymo, 1988), before yielding to the larger 100,000-yr fluctuations of the Brunhes Chron (Shackleton and Opdyke, 1976; Hays et al., 1976). Any effects of Northern Hemisphere ice sheets and North Atlantic SST (and of glacially induced $\mathrm{CO}_{2}$ fluctuations) on low-latitude climate should thus be registered first as variations of moderate amplitude at the $41,000-y r$ period beginning at $2.65-2.4 \mathrm{Ma}$, and then as changes of larger amplitude at the $100,000-\mathrm{yr}$ period after about $0.7 \mathrm{Ma}$. 


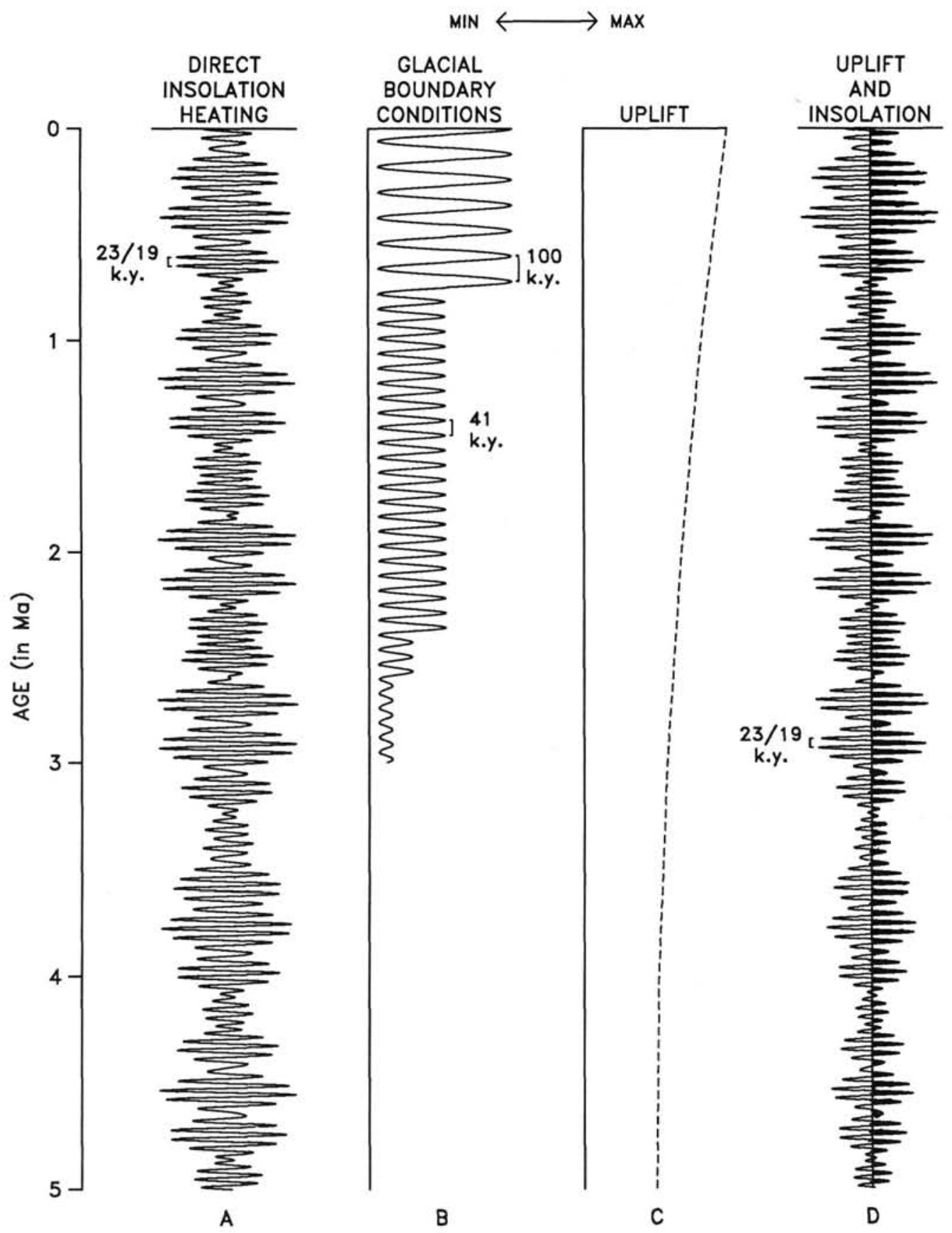

Figure 8. Schematic cartoon of several kinds of climatic controls and of possible linear climatic responses over North Africa and the Atlantic during the last 5 m.y. Maximum amplitudes of controls and responses are arbitrarily normalized. Dominant periodicities are shown by brackets. Lengths of periods are schematic and do not precisely match the time scale. Curve $\mathrm{A}=$ direct insolation heating at precessional period. Curve $\mathrm{B}=$ size of Northern Hemisphere ice sheets (and high-latitude North Atlantic cooling). Curve C = gradual uplift of Tibetan Plateau. Curve D = combined effects of uplift and precessional insolation. For Curve D, two possible responses are suggested: (1) the "two-sided" response (full curve), in which the amplitude of variation increases in both directions; and (2) the "one-sided" response (shaded part of Curve D on right), in which the amplitude increase only occurs in one direction.

Curve $\mathrm{C}$ shows a slowly evolving response through the last $5 \mathrm{~m} . \mathrm{y}$. based on published summaries of uplift histories. The uplift of Tibet over the last $5 \mathrm{~m} . \mathrm{y}$. has been portrayed as starting at elevations slightly more than half of those today and rising quasi-exponentially toward the present (Mercier et al., 1987). The shape of the uplift curve is obviously highly schematic; faster uplift may have occurred during some short- term intervals. For lack of more detailed knowledge, we show a smooth trend that could be projected back prior to $5 \mathrm{Ma}$.

Not shown in Figure 8 are curves representing the effects of changes in equatorial or antarctic SST, because their shapes are uncertain. Both would include high-frequency variations at orbital periods, but the equatorial curves would probably be far more dominated by the 23,000 -yr cycle of 
orbital precession (Gardner and Hays, 1976; McIntyre et al., 1989; Karlin et al., this vol.) than would the circumantarctic responses, which contain other strong orbital periodicities (Hays et al., 1976). Both would also have abrupt and prominent coolings in the late Pliocene, shown for Antarctica by Cieselski and Grinstead (1986) and by Mead et al. (1988), and bracketed in the late Pliocene for the equatorial Atlantic by studies of Thunell and Belyea (1982) and Karlin et al. (this vol.). Other major long-term changes that occurred in the Southern Ocean are (1) a large-scale cooling between 4.3 and 3.7 Ma (Cieselski and Weaver, 1974; Kennett and Vella, 1975; Keany, 1978), (2) a less distinct cooling near 1.6 Ma (Hays and Opdyke, 1967), and (3) a middle Pleistocene antarctic warming after 0.5 Ma (Kennett, 1970; Keany and Kennett, 1972).

Several of the kinds of climatic controls discussed previously may interact and yield combined responses. For example, the combined effects of uplift and precessional insolation heating might be a slow amplification of both maxima and minima in precessionally driven signals, shown by curve $D$ in Figure 8. Precession causes north-south shifts in the region of strong moisture gradients across the Sahel (Kutzbach, 1981). Uplift could slowly reinforce this trend through time by making wet intervals wetter in the tropics and southern Sahel (because of increased precipitation, as shown in Fig. 4), and by decreasing (or not increasing) precipitation in the northern Sahara. With larger extremes of wet climate to the south and dry climate to the north, a transitional zone could exist in the southern Sahara and northern Sahel, which is alternately affected by increased extremes in each direction (wet and dry), probably at the tempo of precessional insolation.

For cases in which a climatic indicator is sensitive only to one part of the precessional forcing, the response to precession might be "one-sided," with slow amplification or suppression of the signal in one direction. Mediterranean sapropelitic muds may be an example of such a "one-way" response. At orbital time scales, the deposition of sapropelitic stagnant muds appears to be a response to strong (precessional) insolation maxima, with no obvious sensitivity to the strength of insolation minima (Rossignol-Strick, 1983).

Further complications could arise from the interactions of controlling factors. For example, tectonic uplift might change the precessional sapropel trend through time by slowly increasing precipitation and thus Nile flow, either due to greater tropical and Sahelian rainfall caused by Tibetan uplift (Fig. 4) or to local East African uplift and orographic trapping of rainfall. In such a case, the combined response would then be a long-term oscillatory drift in one direction, with maxima of increasing amplitude but minima remaining at zero (shaded part of curve D in Figure 8). In fact, sapropels have become markedly better developed in the last 3 m.y. (Kidd et al., 1978; Thunell et al., 1984). Other interactions are possible between ice sheets and insolation, or between uplift and ice sheets. At this point, however, the nature of interactions of this kind is not clear.

In summary, Figure 8 provides an initial conceptual framework for analyzing the basic form of Pliocene-Pleistocene climatic trends reported in this volume. Even without longterm $\delta^{18} \mathrm{O}$ records that will eventually provide time scales for more exact analysis of variance in the orbital band, the "look" of these various long-term trends suggests much about the nature of factors controlling climate and their long-term evolution.

Long-term signals analyzed from Leg 108 (Figs. 9-11) resemble several features of the conceptual trends shown in Figure 8. All signals contain high-frequency variations in the orbital band, similar to curve A. The terrigenous sediment flux at Site 659 (Fig. 9) has a peak at the precessional period but a relatively small amount of total variance; a large amount of variance also occurs at lower frequencies (Tiedemann et al., this vol.). Sampling at closer intervals will be required to resolve the orbital-scale distribution of variance. In the late Pliocene signal of equatorial SST (Karlin et al., this vol.), the precessional component is dominant within the primary orbital band.

The records of opal and terrigenous deposition at equatorial Sites 662/663 and 664 (Fig. 10; data from Ruddiman and Janecek, this vol.) have some similarity to curve B: both signals show fairly large increases in percentages (and burial fluxes) near $2.5 \mathrm{Ma}$ as well as earlier less-prominent increases at 3.6-3.4 Ma and 3.0-2.9 Ma. The 2.5-Ma increase is best developed in the opal records and in the dust record at more distal Site 664 . The $2.5-\mathrm{Ma}$ timing suggests a possible connection to the onset of large ice sheets in the Northern Hemisphere. However, the subsequent orbital-scale percentage oscillations appear to occur mainly at frequencies higher than the $41,000-$ and $100,000-y r$ rhythms that dominate Northern Hemisphere $\delta^{18} \mathrm{O}$ (ice volume) during, respectively, the Matuyama (Ruddiman et al., 1986) and Brunhes Chrons (Shackleton and Opdyke, 1976, Hays et al., 1976). Thus, while ice sheets may be the ultimate initiator of these changes, the actual response in the orbital band may involve forcing via some kind of intermediary in the antarctic region (Gardner and Hays, 1976; McIntyre et al., 1989; Ruddiman and Janecek, this vol.).

Two other records with some similarity to curve B are the fluxes of marine organic carbon and opal at Site 658 (Fig. 11; after Stein et al., this vol., and Tiedemann et al., this vol.). These signals mainly reflect changes in paleoproductivity caused by changing nutrient supply, which in turn can change because of upwelling activity or river fluxes. The trend of the marine carbon flux (Fig. 11) is actually almost inverse to curve $\mathrm{B}$, in that it shows an abrupt step-function decrease at $3.1 \mathrm{Ma}$ (the time of increased opal flux). This decrease is interpreted as a decrease in river-borne carbon and nutrients caused by the aridification of adjacent sections of the western Sahara (Stein et al., this vol.). The increase in opal is ascribed to stronger trade winds and upwelling in northern summer (Tiedemann et al., this vol.). In both cases, however, the major changes (decreased carbon, increased opal) at $3.1 \mathrm{Ma}$ precede the major change in $\delta^{18} \mathrm{O}$ and the onset of North Atlantic ice rafting by about $0.5 \mathrm{~m}$.y. This suggests that these two responses are not causally linked but are instead independent responses to some other kind of forcing (such as the intensification of coastal trade winds and drying of the northwestern African margin in summer by tectonic uplift noted earlier).

As at Sites 662/663 and 664 (Fig. 10), the records of terrigenous deposition at Sites 659, 660, and 661 (Fig. 9) show a long-term increase similar in some respects to curve D, except for the well-marked early Pliocene steplike increase near 4.5-4 Ma. The influx of early Pliocene terrigenous sediment cannot be caused by Northern Hemisphere ice sheets, which first appeared about 1.5 m.y. later. Episodic mountain glaciation occurred during the early Pliocene in the Northern Hemisphere, but there is no evidence of significant ice sheets (Einarsson and Albertsson, 1988; Jansen et al., in press). Although ice sheets may possibly have contributed to some of the later (post-2.5 Ma) increases in terrigenous dust fluxes, the large early Pliocene increases (Sites 659-661) and the gradual background increases require some other kind of forcing.

Two of the remaining sources of long-term forcing of terrigenous fluxes (and, by inference, African aridity) are (1) gradual changes in climate in Antarctica, transmitted to the 


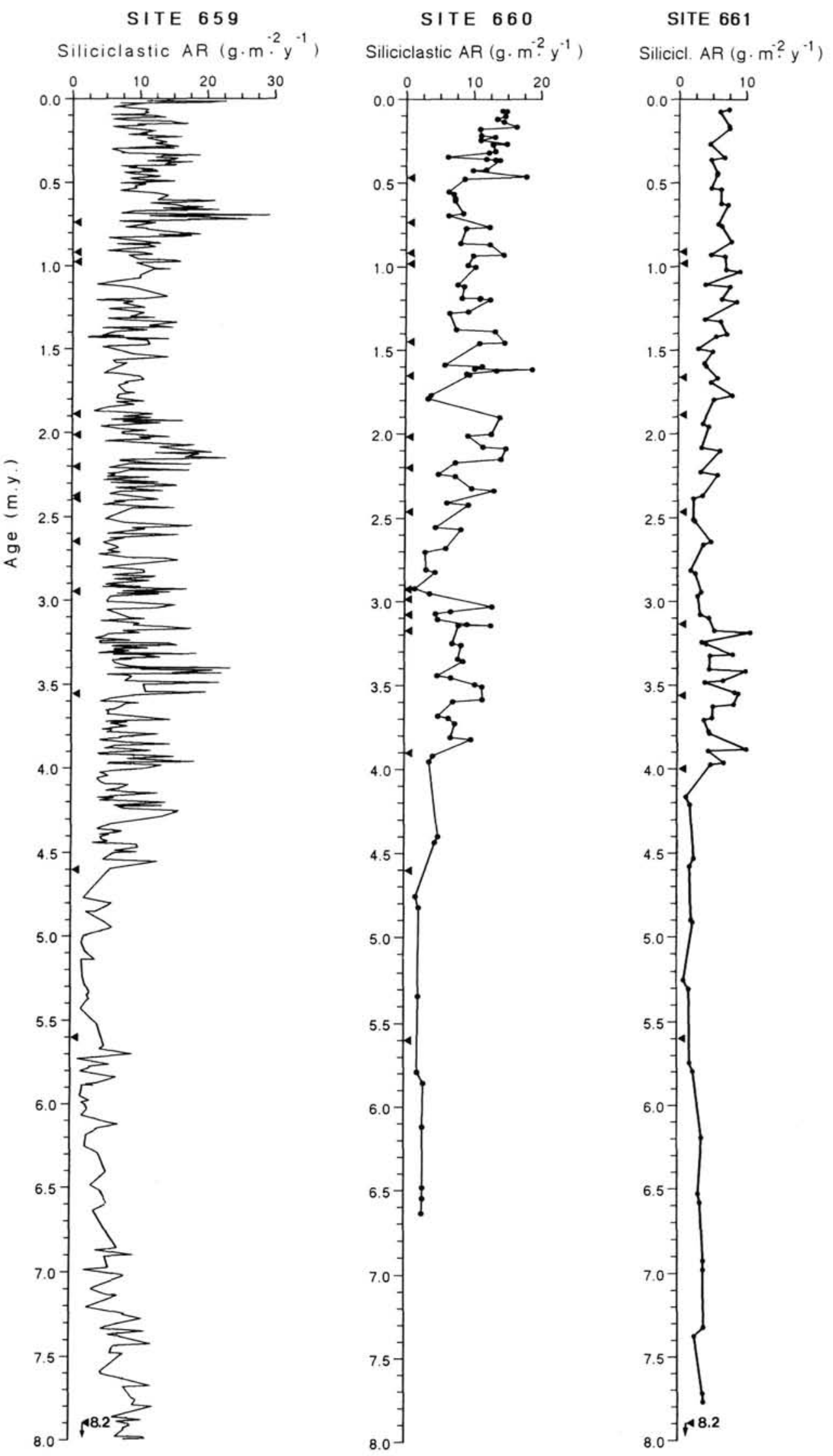

Figure 9. Mass accumulation rates of siliciclastic (eolian) dust $>6 \mu \mathrm{m}$ (in $\mathrm{g} / \mathrm{m}^{2} / \mathrm{yr}$ ) at Sites 659,660 , and 661 based on Tiedemann et al. (this vol.). 

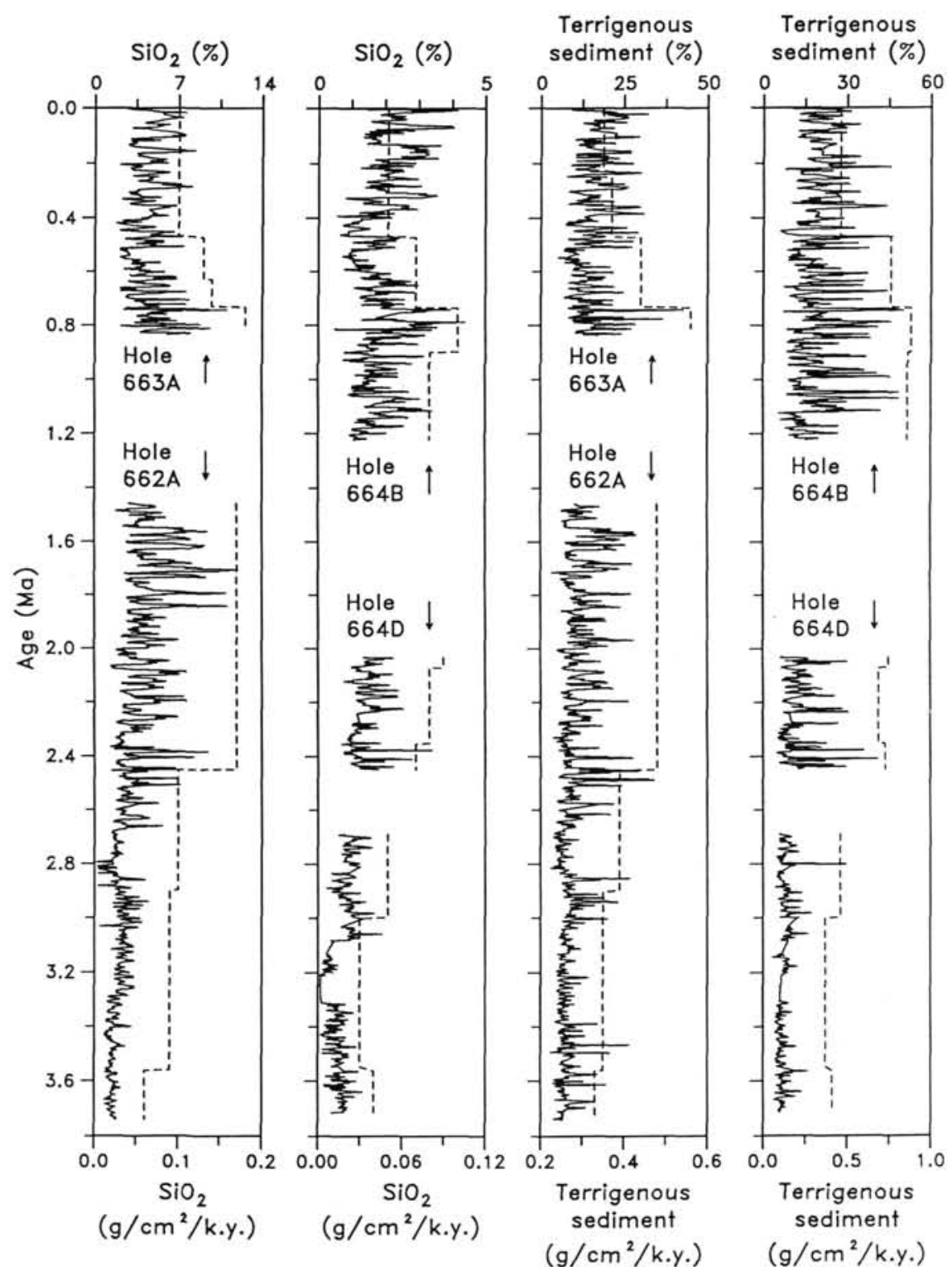

Figure 10. Pliocene-Pleistocene records of terrigenous (eolian) dust (no lower size limit) and of biogenic opal from equatorial Atlantic Sites 662/663 (composite) and 664 (after Ruddiman and Janecek, this vol.). Average mass accumulation rates (in $\mathrm{g} / \mathrm{cm}^{2} / \mathrm{k} . \mathrm{y}$.) between widely spaced chronostratigraphic datums are shown by dashed lines, and detailed percentage variations by solid lines.

equatorial Atlantic and Africa; and (2) tectonic uplift. The next section contains a more thorough investigation of these two factors.

\section{LATE CENOZOIC CLIMATIC EVOLUTION}

In this section, we summarize the evolution of climate in North Africa and in the equatorial Atlantic during the last 8 m.y., the interval for which we have new data from Leg 108 , and we also review the broad outline of changes earlier in the Cenozoic. Influxes of terrigenous sediment from North Africa constitute the largest single source of Leg 108 information at this time. Here we interpret these signals as primarily reflecting the influx of windblown terrigenous dust, although hemipelagic redistribution of sediment also occurs, especially at sites along the continental margin. Calculating only the $>6-\mu \mathrm{m}$ component of terrigenous fluxes at sites from the continental margin (Tiedemann et al., this vol.) helps to minimize the effect of hemipelagic redistribution of fluvial and other sediment.

We consider two possible origins of these dust influxes. First, as conventionally interpreted, the influxes may indicate the degree of aridification on the continent, with reduced vegetation cover during dry intervals that exposes soils and other debris to strong winds. Thus, stronger influxes would indicate greater aridity, particularly in semiarid regions. In addition, the dust influx levels may reflect episodic moisture variability in North Africa. On the scale of shorter-term (orbital) cycles, moist intervals may be important in replenishing the soils that then become available for erosion and transport during subsequent dry intervals (Rognon, 1980). On a global scale, the largest dust sources include both arid and semiarid regions, but the fully arid regions (including stony 

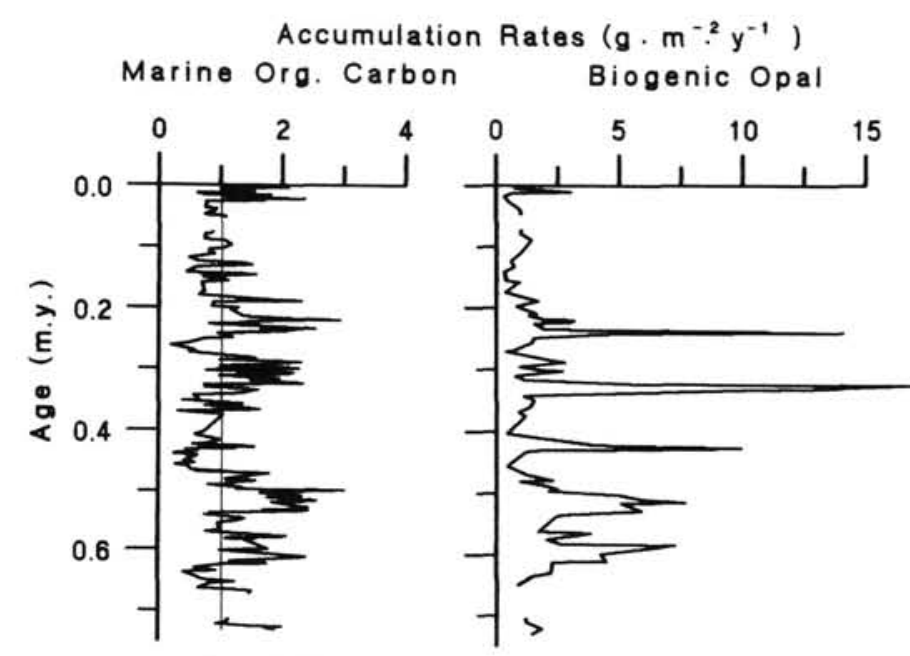

H I A T U S
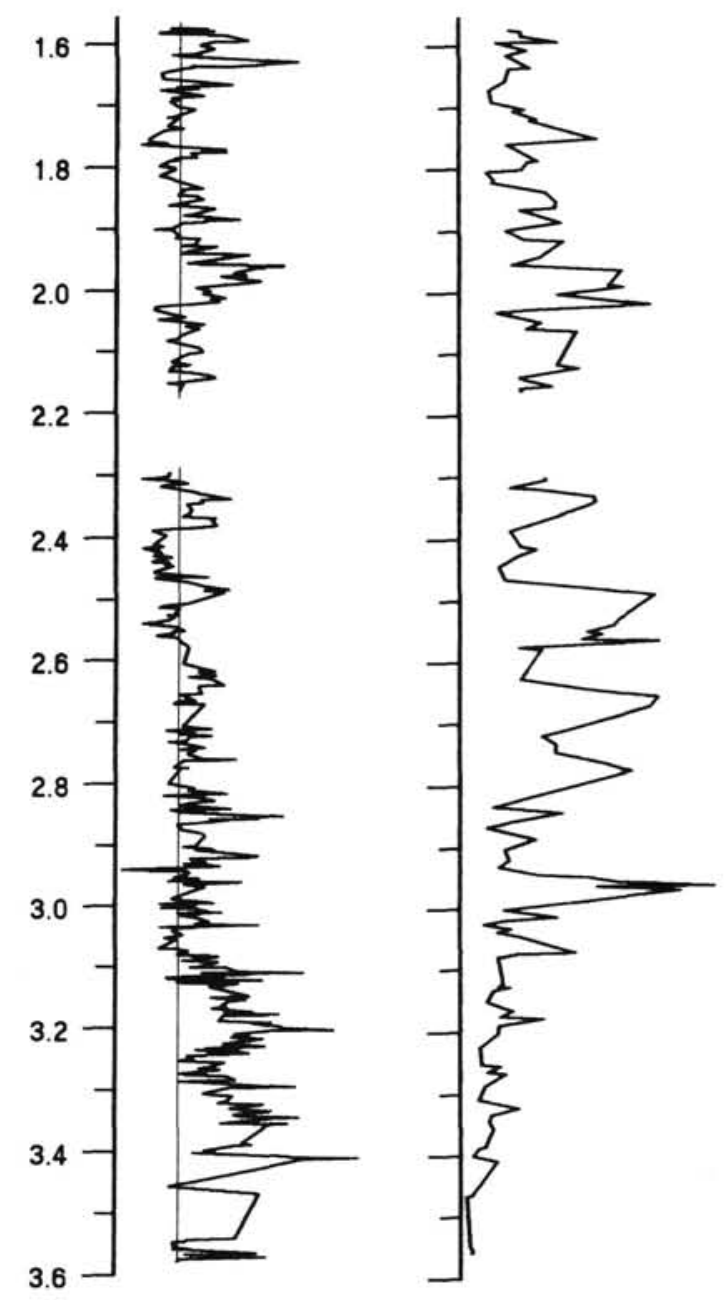

Figure 11. Mass accumulation rates (in $\mathrm{g} / \mathrm{m}^{2} / \mathrm{yr}$ ) of marine organic carbon (after Stein et al., this vol.) and biogenic opal (after Thiedemann et al., this vol.) at Site 658 during the late Pliocene and late Pleistocene. deserts, varnish-indurated plains, and dune fields) appear much less important for dust generation than the alluvial fans and floodplains of semiarid areas (Pye, 1987).

We will thus interpret Leg 108 dust trends mainly in terms of the mean aridity levels in semiarid regions as well as briefly note the possible effect of moisture variability. Other factors may also be important, such as mean wind speed and sporadically strong wind maxima.

\section{Miocene and Earlier Climatic History}

A complete picture of the long-term history of North African climate cannot be compiled from land sections because the rare records of Cenozoic vegetation from the African continent are, for the most part, poorly dated and short in duration. The most striking fact is the existence of rain-forest floras in Libya and Egypt during the Cretaceous and Eocene (Axelrod and Raven, 1978). Today, these are desert regions that have varied between semiarid and hyperarid during the late Pleistocene and Holocene (Ritchie et al., 1985). This vegetational change indicates major long-term aridification of these regions, but the extent and timing of this change is uncertain.

Most records of late Cenozoic vegetation come not from regions of modern desert, but from East Africa, where local and regional uplift and resulting lapse-rate and rain-shadow effects complicate climatic interpretations (Bonnefille, 1985). Early Miocene vegetation in East Africa suggests the existence of a well-marked dry season (Axelrod and Raven, 1978; Bonnefille, 1984), although mammalian remains in the same area have been interpreted as indicating the persistence of evergreen forest in a belt stretching to the Indian Ocean (Andrews and Van Couvering, 1975). Sparse vegetational evidence from a higher terrain in the Sahara during the middle Miocene has variously been interpreted as indicating temperate rain forest (Quezel, 1978) or savanna-woodland (Axelrod and Raven, 1978), implying subsequent aridification.

One view is that the Sahara Desert did not come into existence until the late Miocene or Pliocene (Axelrod and Raven, 1978; Maley, 1980; van Zinderen Bakker and Mercer, 1986); however, this conclusion seems premature given the lack of well-dated land records and the discontinuous nature of the records that do exist. In contrast, evidence from marine cores indicates the existence of coastal dune sands as early as the early Miocene (Sarnthein and Diester-Haass, 1977). Sarnthein et al. (1982) suggested that a belt of dune sands has existed continuously since at least the early Miocene, despite subsequent intervals of variable humidity and aridity. The extent of these dunes in the interior of Africa is unknown. In summary, there is general agreement that North Africa has become progressively drier throughout at least the last half of the Cenozoic, but this conclusion is based on a remarkably sparse continental record. And there is substantial disagreement as to when the main phase of aridification occurred.

Leg 108 records provide continuous signals of terrigenous (presumably eolian) sediment influxes since the late Miocene. Influx data are available at moderate resolution from Site 659 and at lower resolution from Sites 660 and 661 (Fig. 9). The terrigenous flux slowly decreases from 8 to $5 \mathrm{Ma}$ at summerplume Site 659 and winter-plume Site 661, but it remains roughly constant from $6.5-5 \mathrm{Ma}$ at winter-plume Site 660 . In comparison, the terrigenous dust flux at Deep Sea Drilling Project (DSDP) Site $366\left(4^{\circ} \mathrm{N}\right.$ on the Sierra Leone Rise) shows an apparent influx maximum between 8 and 5 Ma (Stein 1985b, 1986). At DSDP Site 397 on the continental slope farther north $\left(27^{\circ} \mathrm{N}\right)$, terrigenous fluxes were generally low during the late Miocene (Stein, 1985a), but moderate-sized dust influx maxima occurred between 7.5 and $7 \mathrm{Ma}$ and between 6 and $5.5 \mathrm{Ma}$ (Sarnthein et al., 1982; Stein, 1985a). 
In general, the terrigenous fluxes at these sites were low (and in some cases slowly declining) during most of the latest Miocene, although exceptions to this pattern occur. This suggests that the African climate was relatively moist, and becoming slowly more so, between 8 and 5 Ma. Moisture variability may also have been low and slowly declining.

For Miocene and earlier intervals, several factors could contribute to long-term changes in moisture over Africa:

1. the northward motion of North Africa from a position in the wet equatorial belt into drier subtropical latitudes (Axelrod and Raven, 1978), mostly prior to $40 \mathrm{Ma}$;

2. the elimination of shallow marine embayments in the Niger River area during the Oligocene and in the Nile River delta during the middle Miocene (Maley, 1980);

3. the slow closure of the Tethys Seaway until the middle Miocene, reducing oceanic moisture sources to northern and eastern Africa (Axelrod and Raven, 1978);

4. the large-scale uplift of plateaus in East Africa and of the Atlas Mountains in northwestern Africa during and since the early Miocene, forming barriers to oceanic moisture fluxes (Axelrod and Raven, 1978; van Zinderen Bakker and Mercer, 1986);

5. the development since the middle Miocene of the TEJ (Fig. 3B), which may enhance the normal Hadley cell subsidence of dry air in the Sahara (Flohn and Nicholson, 1980);

6 . the cooling and glaciation of the antarctic continent, with effects on tropical Africa (van Zinderen Bakker and Mercer, 1986) and on equatorial circulation; and

7. the drying of the Mediterranean Sea during the latest Miocene (Messinian) interval (Ryan, Hsü, et al., 1973).

Three of these factors (plate motion, the closure of the Tethys Seaway, and withdrawal of shallow seas) are irrelevant in explaining trends as recent as the late Miocene. Northern Hemisphere ice sheets can also be ruled out for this latest Miocene interval. Although a complete drying out of the Mediterranean might impact moisture fluxes in south Saharan and Sahelian North Africa, no physical mechanism by which this might have occurred has been convincingly demonstrated. In addition, the Messinian desiccation appears to have been much shorter in duration (less than $1 \mathrm{~m} . \mathrm{y}$.) than the 3-m.y. late Miocene interval (7-4.5 Ma) of low (and declining) dust fluxes.

It is difficult to arrive at a conclusive evaluation of climatic connections between the Southern Ocean and Africa during the late Miocene. There is general agreement that a long-term cooling of the Southern Ocean occurred throughout the latest Cenozoic (Hayes and Frakes, 1975; Kennett, 1977; Keany, 1978; Cieselski and Grinstead, 1986), and the latest Miocene is specifically viewed as a time of additional climatic cooling marked by increases in ice rafting and the extent of biosiliceous sedimentation (Kennett, 1977). If this view is correct, there is no obvious link between the Southern Ocean and the African responses during the latest Miocene. At this point, however, published interpretations of the late Miocene Southern Ocean are based on broadly sampled records that do not definitively clarify the pattern of climate change; thus, forcing from the Southern Ocean remains a possibility.

Local tectonic uplift in East Africa and the Atlas Mountains was rapid in the latest Miocene (King, 1962; Baker and Wohlenburg, 1971). These rising orographic barriers imply, however, a reduction in moisture penetrating into interior Africa, exactly opposite the dust-flux indications of a relatively moist climate. Tibet appears to have been uplifted during the late Miocene (Mercier et al., 1987), although the uplift history is not well defined over intervals of this short a duration. As reviewed earlier, Tibetan uplift predicts wetter summers in tropical Africa and the western Sahel, and drier summers not just in eastern, northwestern, and northernmost Africa (Fig. 7A), but also, according to the Flohn-Nicholson hypothesis, in the central Sahara as well.

If the dust fluxes mainly reflect the degree of aridity in semiarid regions, then the low (and declining) late Miocene dust fluxes registered at winter-plume Sites 660 and 661 (Fig. 9) would agree with the uplift-experiment simulation of increasing moisture over western Sahelian North Africa (Fig. 7A). The decreasing dust fluxes farther north at summerplume Site 659 (Fig. 7A) would, however, disagree with the drying of the central Sahara during this interval because of subsidence associated with the strengthened TEJ, as required by the Flohn-Nicholson hypothesis. If, on the other hand, the dust fluxes are attributed to the amplitude of arid/humid cycles, then the reduced dust fluxes at all sites would be opposite those expected from uplift, which predicts increasing moisture variability at all sites.

\section{Pliocene Climatic History}

Leg 108 data suggest several significant changes or trends during the Pliocene: (1) an increase in terrigenous fluxes at Sites 659-661, particularly between 4.5 and $3.9 \mathrm{Ma}$, and possibly again near 2.6-2.3 Ma (Fig. 9 after Tiedemann et al., this vol.); (2) an abrupt decrease in river-borne nutrients along the African continental margin at Site 658 near 3.1 Ma (Fig. 11; Tiedemann et al., this vol.; Stein et al., this vol.); and (3) a slow, progressive increase in winter-plume dust flux at equatorial Site 662 , overprinted by a major, more rapid increase at Site 662 and 664 near 2.5 Ma (Fig. 10; Ruddiman and Janecek, this vol.). In addition, the influx of a diverse assemblage of freshwater diatoms to Site 658 decreased near 2.8 Ma (Stabell, this vol.), but the influx of windblown Melosira to equatorial Sites 662 and 664 apparently increased near 2.5 Ma (Pokras and Ruddiman, this vol.).

Each of these changes has been interpreted as indicative of increasing aridification in the respective dust source areas or coastal-margin regions (assuming that the dust fluxes indicate mean levels of aridity). If correct, this would indicate significant aridification in both summer-plume and winter-plume source areas between $18^{\circ} \mathrm{N}$ and $30^{\circ} \mathrm{N}$ in the central Sahara and northern Sahel between 4.5 and 3.9 Ma (Prospero, 1981; D'Almeida, 1986); abrupt local aridification of the western Saharan margin at $21^{\circ} \mathrm{N}$ near 3.1-2.4 Ma (Tiedemann et al., this vol.; Stabell et al., this vol.); and additional aridification of winter-plume source areas in the southern Sahara and the Sahel near 2.5 Ma (Ruddiman and Janacek, this vol.).

Differences or disagreements in dust-flux history among sites could reflect complications from such factors as local changes in atmospheric circulation patterns and wind strength or in the redistribution of hemipelagic sediment on the seafloor. One example is the lack of any base-line increase in the dust flux to Site 659 between 4 and $1 \mathrm{Ma}$, implying no fundamental change in mean aridity across the broad SaharanSahelian source area during that interval (Tiedemann et al., this vol.); this contrasts with the evidence for aridification of the adjacent northwestern Saharan margin near 3.1 Ma (Stein, 1985a; Stein et al., this vol.). Similarly, the Site 659 dust flux does not register the major increase found in equatorial Sites 662 and 664 near 2.5 Ma (Ruddiman and Janecek, this vol.), even though there is a large area (south Saharan and north Sahelian) that is a common source region for dust fluxes to these sites.

Nevertheless, most of the data are broadly consistent with a trend of stepwise aridification of Africa from north to south. The initial early Pliocene (4.5-4 Ma) increase in Saharan and 
Sahelian dust is registered at Site 659 in the summer dust plume and in proximal Sites 660 and 661 in the winter dust plume. The late Pliocene (3.1 Ma) aridification appears to be concentrated along the northwestern margin of the Sahara). The still later $(\sim 2.5 \mathrm{Ma})$ increase in dust affects all winterplume sites, particularly the distal winter-plume sites on the equator. The equatorial sites may register this latter change with such marked intensity in part because of changes in atmospheric circulation along the equator (Ruddiman and Janecek, this vol.)

The amplitude of cycles of aridity and humidity may also be an important factor in determining dust fluxes. If so, the Pliocene increases in dust fluxes from Africa would call for an increase in the amplitude of arid/humid cycles, with important stepwise increases at 4 and $2.5 \mathrm{Ma}$, in addition to general shifts toward increased aridity. In any case, all of these records agree at the most basic level: by the end of the Pliocene, African dust fluxes had become considerably higher than they were earlier in the Pliocene, implying some combination of increasing aridity, increasing amplitude of arid/humid cycles, and possibly increasing wind speed.

The Leg 108 data thus confirm the view previously put forward based on discontinuous land records that North Africa experienced large-scale aridification in the Pliocene (Axelrod and Raven, 1978; Maley, 1980; van Zinderen Bakker and Mercer, 1986). Whether or not this interval marks the initial establishment of the hyperarid Sahara desert depends in large part on if the early Miocene dune sands reported by Sarnthein and Diester-Haass (1977) were largely coastal or also covered the interior of North Africa. At the least, the Leg 108 data favor a major Pliocene aridification of North Africa.

From the list of potential causal factors noted in the previous section, we can again eliminate changes in plate motion, in shallow flooding of the African continent, and in the closure of the Tethys Seaway. Several possible sources of forcing remain: (1) end-Messinian flooding of the Mediterranean; (2) late Pliocene emergence of the Panamanian Isthmus; (3) late Pliocene onset of Northern Hemisphere glaciation; (4) changes in antarctic climate; (5) local uplift of moisture barriers in East Africa and the Atlas Mountains; and (6) uplift of Tibet.

We again omit detailed consideration of the end-Messinian flooding of the Mediterranean as a climatic factor. The reopening of the Mediterranean to Atlantic waters was very rapid and occurred near $5 \mathrm{Ma}$ or shortly thereafter (Ryan, Hsü, et al., 1973), whereas the early Pliocene dust-flux increases at Site 659 appear to have been centered near 4.5-4 Ma (Fig. 9; Tiedemann et al., this vol.). In addition, it would also be highly speculative to try to link the gradual Pliocene (5-3 Ma) closure of the Panamanian Isthmus (Keigwin, 1982) to the increase in African dust fluxes. And, in any case, increases in dust continued well after these tectonic changes had ceased.

The onset of Northern Hemisphere ice sheets of significant size dates from the interval 2.65-2.4 Ma. Some $\delta^{18} \mathrm{O}$ signals show fairly large oscillations prior to this time (e.g., Sarnthein and Tiedemann, this vol.), but these probably reflect changes in ocean temperature and antarctic ice volume. The lack of ice-rafted sediment argues against Northern Hemisphere ice of significant volume prior to $2.6 \mathrm{Ma}$ : trace amounts of ice-rafted sand found in early Pliocene sediments from the Norwegian Sea are 3-4 orders of magnitude less abundant than during the late Pliocene and Pleistocene glaciations (Jansen et al., in press).

These low influxes suggest cooler climates and local mountain glaciation around the Atlantic, consistent with latest Miocene and early Pliocene tillites high on Icelandic stratovolcanoes (Einarsson and Albertsson, 1988). Thus, there is no basis for calling on major Northern Hemisphere ice sheets (and their large-scale effects on hemispheric circulation trends) to explain the increased influxes of African dust between 4.5 and $4 \mathrm{Ma}$ (Tiedemann et al., this vol.). Similarly, fluxes of Asian eolian dust to the mid-latitude North Pacific began to increase well before Northern Hemisphere ice sheets appeared (Leinen and Heath, 1981; Janecek, 1985),

Later, glaciation may have increased at higher elevations of Iceland near 3.1 Ma (Einarsson and Albertsson, 1988), but there was no increase in the deposition of ice-rafted sediment in the Norwegian Sea (Jansen et al., in press). Thus, it does not appear that the inferred aridification of northwesternmost Africa and the apparent increase in trade-wind-induced upwelling at 3.1 Ma (Tiedemann et al., this vol.; Stein et al., this vol.) can be ascribed to major ice-sheet formation. Well-dated sequences in the Tjornes region show that an Icelandic ice sheet first reached the coast just after $2.5 \mathrm{Ma}$ (Einarsson and Albertsson, 1988), coincidental with the first occurrence of large ice sheets elsewhere in the Northern Hemisphere. Although ice sheets can thus be ruled out as a key factor in the Pliocene aridification of Africa prior to $2.5 \mathrm{Ma}$, it is possible that the general cooling trend in the Northern Hemisphere and the aridification of Africa are linked, possibly each as an independent response to some other common forcing.

Two changes that are contemporaneous with the onset of Northern Hemisphere glaciation are the abruptly increased fluxes of both opal and winter-plume dust along the equator near 2.5 Ma (Fig. 10). Ruddiman and Janecek (this vol.) suggest that the opal increase is most readily explained by a periodic redirection of the southern winter trade winds toward a more zonal flow and away from their present monsoonal curvature northeastward into North Africa (Fig. 2B). This would increase equatorial upwelling (and opal deposition) and might also enhance Sahelian aridity (and winter-plume dust fluxes). Coppens and Koeniguer (1976) cite paleobotanical evidence for late Pliocene drying in the Lake Chad region.

Increases in the strength and/or southward extent of the northeasterly winds that carry winter-plume dust at $1.5-3 \mathrm{~km}$ during Northern Hemisphere winter are also possible factors in these winter-plume dust increases, but (as summarized earlier) GCM studies do not clearly indicate any effect of ice sheets on these winds. The only grain-size study of winterplume dust found evidence suggesting weaker rather than stronger winds during the last glaciation (Parkin and Padgham, 1975).

Ruddiman and Janecek (this vol.) suggested that the rough synchroneity of these opal/dust flux changes with the appearance of Northern Hemisphere ice sheets may be because of forcing mediated from the Southern Ocean, which also experienced significant changes in circulation at this time. Radiolarian evidence from the southwestern Atlantic suggests a major cooling and polar-front advance between 2.9 and $2.4 \mathrm{Ma}$ (Cieselski and Grinstead, 1986; Mead et al., 1988). Opal fluxes to the seafloor at southeastern Atlantic Site 704 near the present antarctic divergence also increased substantially near $2.4 \mathrm{Ma}$ (P. Froelich, pers. comm., 1988). The latter change may have been part of a redistribution of opal deposition away from regions near Antarctica where the sea-ice cover increased, toward more northerly locations near the antarctic divergence. Although core coverage of the Southern Ocean is still very limited, available evidence suggests large changes in Southern Ocean circulation between 3.1 and $2.4 \mathrm{Ma}$. These changes may in turn be linked in some way to the onset of Northern Hemisphere ice sheets (Mead et al., 1988).

Evidence also exists that the early Pliocene African dustflux increase (4.5-4 Ma) is linked to climatic changes in the Southern Ocean in the total absence of Northern Hemisphere ice sheets. Several studies have identified a major cooling in 
the Southern Ocean at this time (Cieselski and Weaver, 1974; Kennett and Vella, 1975; Keany, 1978). Bornhold (1983) noted a major increase in ice rafting at southwestern Atlantic DSDP Sites 513 and 514 between 4.2 and $3.8 \mathrm{Ma}$. In addition, increases in fluxes of dust during the early Pliocene to DSDP cores on the Lord Howe Rise may record increasing Australian aridity (Stein, 1986), perhaps related to cooling of the Southern Ocean.

Continued cooling of the antarctic region may also have contributed to the progressive increase in winter-plume dust fluxes after 2.5 Ma (Fig. 10). Antarctic sediments near the modern antarctic convergence show a shift from calcareous to siliceous deposition near $1.6 \mathrm{Ma}$ that may be indicative of cooling and/or restructuring of circumantarctic circulation (Hays, 1965; Hays and Opdyke, 1967). More recent work on Leg 114 sediments by Froelich (pers. comm., 1989) suggests a major shift from calcareous to biosiliceous sedimentation at about $1.8 \mathrm{Ma}$.

Caution is needed in linking the African dust influx history to the fragmentary time and space coverage of climate changes in the Southern Ocean. Nevertheless, there are significant indications of linkages between the stepwise cooling of the Southern Ocean and the stepwise increases in African dust during the Pliocene. This linkage is similar to connections between antarctic and equatorial circulation observed at orbital periodicities during the late Pleistocene (McIntyre et al., 1989). If one assumes that such a linkage does exist at the longer time scales, the ultimate source of forcing of both the Southern Ocean and African responses still remains to be identified.

Uplift was particularly rapid in East Africa during the Pliocene, particularly the late Pliocene (Baker and Wohlenberg, 1971). If this barred southern trades over the Indian Ocean from reaching as far into Africa as before (Axelrod and Raven, 1978), it may have caused aridification of equatorial Africa west of the rising barrier. The uplift of the Atlas Mountains (King, 1962) may have reduced winter influxes of Atlantic moisture into northwestern Africa in a similar fashion.

As noted earlier, Ruddiman and Kutzbach (in press) concluded that Tibetan uplift has been an important factor in the climatic evolution of southwestern Asia and the Mediterranean during the Pliocene. This conclusion was based on the agreement between the uplift-experiment simulation of significant summer drying in these regions (Fig. 7A) and several kinds of affirmative geologic evidence (Maley, 1980; Traverse, 1982; Suc, 1984; Thunell et al., 1987).

As discussed earlier, a key question for the history of African aridity is whether this uplift-induced drying extended southward into central North Africa. Although the uplift simulation constrains the subsidence and drying farther to the north over the Mediterranean, the hypothesis of Flohn and Nicholson (1980) suggests that the strengthening of the TEJ over Sahelian Africa because of Tibetan uplift would increase aridity in the region of modern-day subsidence over Saharan Africa north of the TEJ axis. If this hypothesis is correct, then Tibetan uplift could be involved in the three phases of Pliocene aridification of North Africa discussed earlier: (1) the increased summer-plume and winter-plume dust fluxes at 4.5-4 Ma; (2) the aridification of the western Saharan margin near 3.1 Ma (also suggested by increased dust fluxes at several DSDP summer-plume dust sites (Stein and Sarnthein, 1984; Stein, 1985a, 1986); and (3) the later winter-plume aridification at $2.5 \mathrm{Ma}$ also suggested by changes in pollen (Bonnefille, 1983; Maley, 1980), in antelope taxa (Vrba, 1985), and in micromammal populations (Wesselman, 1985).

Uplift may also have affected Pliocene climate along the northwestern African margin via changes in the subtropical high over the eastern North Atlantic. Kutzbach et al. (in press) noted increased subsidence in the summer west of the Canary Islands with uplift, and results in Ruddiman and Kutzbach (in press) showed very large increases in trade-wind strength in summer along the African coast north of $20^{\circ} \mathrm{N}$, apparently in association with this increased subsidence. These results are in accord with, and may provide an explanation for, the increase in coastal upwelling inferred from opal fluxes at Site 658 (Tiedemann et al., this vol.) and the coincident drying along the continental margin. Similar trends have been detected farther north at DSDP Site $397\left(27^{\circ} \mathrm{N}\right)$ during the same Pliocene interval, well within the region of summer upwelling.

The uplift experiment also simulates changes that are favorable to increasing the eolian dust fluxes by increasing the variability of moisture over North Africa. The juxtaposition of wetter tropics and drier subtropics (Fig. 7A), because of uplift, should strengthen the zonal moisture gradient in summer over Sahelian North Africa. Combined with high-frequency fluctuations in the monsoonal inflow from the Atlantic forced by precessional insolation heating (Fig. 4; Kutzbach, 1981; Pokras and Mix, 1985, 1987), this could increase the range of moisture variability in the Sahelian boundary zone and thus enhance dust production and availability.

In possible agreement with this prediction, Maley (1980) noted a contrast between vegetative evidence for drying of the northeastern Sahara and lake-level evidence for increased moisture in the south central Sahel during the early Pliocene. Although this pattern is consistent with an increased moisture gradient, the lack of adequate time controls and the likely aliasing caused by orbital frequency variations make a firm conclusion impossible.

A similar contrast in moisture trends can be found within East Africa during the late Pliocene. Long-term trends in $\delta^{13} \mathrm{C}$ from deposits in several regions imply a general shift to vegetation with more $\mathrm{C} 4$ and fewer $\mathrm{C} 3$ plants, indicating development of a climate that is on average drier (Cerling et al., 1986), in agreement with evidence from pollen (Bonnefille, 1983), antelopes (Vrba, 1985), and fossil micromammals (Wesselman, 1985). On the other hand, sapropel deposits in the Mediterranean become better developed in the late Pliocene (Kidd et al., 1978; Thunell et al., 1984), implying increased runoff in the Nile River, which supplies the low-salinity water that stratifies the upper layer of the Mediterranean and suppresses deep-water renewal (Rossignol-Strick, 1983).

These contrasting trends in East Africa could reflect a long-term drift toward aridity, interrupted by brief intervals of increasingly intense monsoon maxima driven by strong insolation maxima (Figs. 4 and 8). Or they may result from local uplift in East Africa (Baker and Wohlenberg, 1971), with increased orographic focusing of precipitation on northern tropical highland source regions for the Nile, and increased rain-shadow drying elsewhere.

In summary, Pliocene uplift is a possible explanation for both gradual net aridification and increased variability of moisture balance in North Africa, as well as for changes in summer trade winds favorable to increased coastal upwelling. The apparent step increases in dust fluxes in several Leg 108 records would require either that uplift is abrupt and episodic (which cannot be tested given our present lack of detailed knowledge of uplift) or that important thresholds exist within the climate system that can transform gradual uplift into abrupt local responses.

The biggest problem with invoking Tibetan uplift as an explanation for the Pliocene increases in dust fluxes is the low or decreasing dust fluxes previously noted in the late Miocene. Such a trend would seemingly require a cessation of Tibetan 
uplift from $8 \mathrm{Ma}$ (or earlier) until $5 \mathrm{Ma}$, and possibly even some decrease in altitude. Similarly, decreased dust fluxes at winter-plume Sites 660 and 661 near 3-2.5 Ma compared with the preceding (early Pliocene) interval also are difficult to explain by uplift. In fact, no explanation of these reversals in the overall trend toward increased late Cenozoic dust fluxes is currently available.

\section{Pleistocene Climatic Changes}

At several Leg 108 Sites $(658,662$, and 664), major portions of the early Pleistocene sequences were lost to slumping (Figs. 10 and 11). Full climatic sequences throughout the early Pleistocene are available only at Sites 659-661, and they suggest that terrigenous fluxes increased slowly during this interval (Fig. 9). The same trend is suggested by the truncated portion of the lower Pleistocene section at Site 664 (Fig. 10).

For the upper half of the Pleistocene (more or less equivalent to the Brunhes Chron), complete records are available at all the above sites (Figs. 9-11), and several climatic trends are evident: (1) strong decreases in dust and opal fluxes (but increases in dust and opal percentages) in the upper part of the Brunhes Chron at equatorial Sites 663 and 664; (2) increased or continued high terrigenous influxes at Sites 659-661; and (3) a general decrease in opal flux at Site 658 , with periodic interruptions by very strong pulses of opal deposition (see also Stabell, this vol.).

Other Leg 108 data show important changes in the late Pleistocene: (1) high-resolution pollen data from Site 658 suggest a general trend in the last half of the Brunhes toward vegetation typical of arid climates (Dupont et al., this vol.); (2) widely variable influxes of freshwater diatoms to Site 658 suggest large-scale local climatic oscillations, assuming transport is fluvial (Stabell, this vol.); and (3) more variable but increasing influxes of (eolian) quartz and more variable but decreasing fluxes of (riverine) clays and feldspar to Site 658 suggest larger-amplitude climatic variations and a net drift toward more arid climates (Tiedemann et al., this vol.).

Three sources of forcing can be considered on the time scale of the Pleistocene: (1) Northern Hemisphere ice sheets, (2) circumantarctic climatic changes, and (3) tectonic uplift. If the middle Pleistocene change toward larger Northern Hemisphere ice sheets at the 100,000 -yr cycle is a factor in directly forcing climate over North Africa and the equatorial Atlantic, it should result in a trend toward climatic responses of larger amplitude and longer wavelength between 0.9 and $0.4 \mathrm{Ma}$.

In partial agreement with this prediction, several of the responses noted above do show increasing amplitudes during the late Pleistocene. Previous studies of the sparse land record on Africa have inferred the same trend (Quezel, 1978). Several Leg 108 signals also contain obvious 100,000 -yr power in the late Pleistocene. The opal flux at Site 658 registers largeamplitude spikes on every isotopically defined deglaciation and early interglaciation (Fig. 11). In addition, Dupont et al. (this vol.) note $100,000-\mathrm{yr}$ power in several pollen indicators during the Brunhes. Modest $100,000-\mathrm{yr}$ power also appears to be present in the opal percentages at Sites 663 and 664 (Fig. 10 ), but not at the level of dominance observed in the ice-sheet records $\left(\delta^{18} \mathrm{O}\right)$. Tiedemann et al. (this vol.) found peak concentrations of power at a period of $125,000 \mathrm{yr}$ in summer dust plume records, although at a frequency somewhat lower than the $100,000-y r$ ice-sheet changes.

Although it is possible that these changes reflect the presence of $100,000-\mathrm{yr}$ climatic variations in the circulation of the surface ocean and lower atmosphere over Africa and the low-latitude Atlantic, other explanations for most of these signals are possible. In accord with the earlier discussion of late Pleistocene studies, the 100,000 -yr signals recorded at
Site 658 may be the result of sea-level changes along the African margin, accompanied by variations in downslope sediment fluxes and the position of coastal upwelling cells. In any case, paleoproductivity studies from the African margin and eastern equatorial Atlantic give seemingly contradictory results in the late Pleistocene (Curry and Lohman, 1986; Sarnthein et al., 1988; Mix, in press). This may be caused in part by differences in proximity to the African coastal margin and its strong upwelling cells.

Similarly, changes in deep-water circulation and $\mathrm{CaCO}_{3}$ dissolution may leave artifactual 100,000 -yr imprints on percentage variations in opal and terrigenous dust at Sites 663 and 664 that do not reflect actual fluxes from the overlying surface waters. Boyle and Keigwin (1985) found that ice sheets suppressed North Atlantic Deep Water formation during the late Pleistocene at the 100,000 -yr cycle, leading to increased northward penetration of corrosive, southern-source water from the Antarctic during Northern Hemisphere glaciations. Other late Pleistocene studies indicate that significant dissolution has occurred in the equatorial Atlantic at depths below $3500 \mathrm{~m}$ but above $3900 \mathrm{~m}$ (Gardner, 1975; Curry and Lohman, 1986). Thus, Sites 662-664 lie in the upper part of the depth range through which late Pleistocene dissolution has been important. A trend toward increased 100,000-yr dissolution cycles could create artifactual $100,000-y r$ signals in percentage variations of opal and dust (Fig. 10). Additional work will be required to evaluate the strength of $100,000-\mathrm{yr}$ oscillations in Leg 108 records of the late Pleistocene, in order to evaluate fully the direct role of Northern Hemisphere ice sheets.

As in the Pliocene, several late Pleistocene signals suggest some kind of linkage between the Southern Ocean and equatorial circulation. The major decrease in opal and terrigenous fluxes over the last $0.7-0.5 \mathrm{Ma}$ at equatorial Sites 663 and 664 represents a reversal of a long-term increase that had begun prior to $3.7 \mathrm{Ma}$ (Fig. 10) and had culminated in maximum fluxes during the late Pliocene to early Pleistocene. Although this reversal in trend might be caused by changes in local sediment redistribution on the seafloor, Ruddiman and Janecek (this vol.) suggested a climatic explanation in which the previously strong zonal flow of southern trade winds along the equator during the late Pliocene and early Pleistocene may have reverted back to a more meridional flow during Northern Hemisphere summers, thus suppressing opal deposition caused by weaker zonal winds. They also suggested possible forcing from the Southern Hemisphere.

Evidence from the Southern Hemisphere favors some kind of linkage with these equatorial trends. At DSDP Site 532 on the Walvis Ridge beneath the Benguela Current, opal fluxes also decreased substantially during the Brunhes Chron, returning to the lower levels that had prevailed during most of the Gauss Chron prior to an interval of higher values between 3 and $1 \mathrm{Ma}$ (Dean et al., 1984). The similarity of these changes to those in the equatorial Atlantic (Fig. 10) suggests linkage of the responses in these two areas.

In addition, planktonic foraminifers indicate that periodically during the last $0.5 \mathrm{Ma}$ subantarctic surface waters reached temperatures warmer than any that occurred during the Matuyama or lowermost Brunhes Chrons (Kennett, 1970; Keany and Kennett, 1972). Although middle Pleistocene changes in subantarctic radiolarian fauna have been interpreted differently (Hays, 1965; Hays and Opdyke, 1967; Bandy et al., 1971), a decrease in ice rafting subsequent to $0.7 \mathrm{Ma}$ in the southwestern Atlantic sector of the subantarctic (Bornhold, 1983) supports the foraminiferal interpretation. This apparent subantarctic reversion to warmer temperatures also suggests some kind of linkage to equatorial circulation. 
The evidence thus suggests that surface waters from as far north as the equatorial Atlantic to as far south as the subantarctic may have reached some kind of extreme glacial state late in the Pliocene or early in the Pleistocene, before reverting back to an earlier pattern of circulation. Without more detailed evidence from a wider array of sites, it would be premature to try to infer the nature of this physical linkage, including questions as to which of these two regions is forcing the other and the ultimate source of forcing for these changes in the interactive climate system.

Tectonic uplift of the Tibetan Plateau is again a possible source of forcing for several Pleistocene responses over Africa. As in the Pliocene, continued trends toward summer aridity consistent with results from the uplift simulation (Kutzbach et al., in press) occurred in the Mediterranean (Suc, 1984; Thunell et al., 1987) and in East Africa (Cerling et al., 1986). In the Mediterranean, glaciations imposed additional aridity, registered by increased steppe vegetation (Wijmstra and Groenhart, 1983).

This drying trend near the Mediterranean may again have been contiguous with a similar trend in northwestern Africa. Stein (1985a) noted that the complete absence of fluvial muds at near-coastal DSDP Site $397\left(26^{\circ} \mathrm{N}\right)$ during the last $0.5 \mathrm{~m} . \mathrm{y}$. could have resulted from greater aridification in northwestern Africa compared with the Pliocene and earlier Pleistocene. In addition, the pollen influx to Site $658\left(21^{\circ} \mathrm{N}\right)$ partly originates in northwestern Africa and shows a drift toward drier late Pleistocene vegetation (Dupont et al., this vol.). Farther south, decreased fluxes of fluvial clay and feldspar and increased fluxes of quartz to coastal Saharan Site 658 suggest increased Pleistocene aridity (Tiedemann et al., this vol.). These indications of increased aridity are consistent with the Flohn-Nicholson hypothesis that strengthening of the TEJ due to Tibetan uplift would cause aridification of the arid core of the Sahara, even though the model simulation places the major drying farther north over the Mediterranean (Fig. 7A). They are also consistent with the model simulations of Kutzbach et al. (in press) and Ruddiman and Kutzbach (in press) that show stronger summer trade winds and aridity along the northwest African margin because of uplift.

All sites show increased influxes of terrigenous dust through the early Pleistocene, suggesting some combination of increased aridification and increased moisture variability in Saharan/Sahelian source areas. Trends evident in several other signals also suggest an increased amplitude of the aridity/humidity cycles: (1) highly variable fluvial influxes at Site 658 (Tiedemann et al., this vol.; Stein et al., this vol.) and (2) variable freshwater diatom influxes at Site 658 (Stabell, this vol.). These results are also consistent with forcing from Tibetan uplift, provided that the Flohn-Nicholson hypothesis of drying of the central Sahara because of uplift is correct.

Dust influx trends in the late Pleistocene are more complex. The suggestion of a small decrease after $0.5 \mathrm{Ma}$ at Site 659 still leaves the mean dust flux at a level considerably higher than at any time prior to $1.0 \mathrm{Ma}$ (Fig. 9). This implies a continuation of aridity in the summer dust plume source areas consistent with (or at least not inconsistent with) the FlohnNicholson model.

One interpretation for the major decreases in dust fluxes at equatorial Sites 663 and 664 (Fig. 10) is that wetter conditions developed in the southern Sahel and reduced the winter-plume dust fluxes (Ruddiman and Janecek, this vol.). On the other hand, the stable or increasing late Pleistocene dust fluxes at proximal winter-plume dust Sites 660 and 661 (Fig. 9) may point to a continuing trend toward aridity in the source areas for winter-plume dust, with the reduced dust fluxes along the equator reflecting localized circulation changes linked to the Southern Hemisphere changes previously noted.

In short, the full array of Leg 108 dust-flux data from the early and late Pleistocene indicate continuing or intensified aridity in the Saharan/Sahelian source areas for winter and summer dust plumes, possibly accompanied by increasing extremes of wet and dry climate across the strong Sahelian moisture gradient. Each trend is basically consistent with forcing from Tibetan uplift.

\section{ACKNOWLEDGMENTS}

We are grateful for help on board JOIDES Resolution Leg 108 from Captain Ed Oonk, ODP Operations Superintendent Lamar Hayes, and the drillers, engineers, technicians, and other scientific crew members. We also thank Christina Hardy, and Ann Esmay for help with the data compilations and illustrations; and Dave Rea for reviewing the manuscript. The senior author acknowledges support from NSF Grant No. OCE-8608328 from the Marine Geology and Geophysics Program of the Ocean Sciences Section of the National Science Foundation in preparing this manuscript.

\section{REFERENCES}

Andrews, P., and Van Couvering, J.A.H., 1975. Palaeoenvironments in the East African Miocene. In Szalay, F. S. (Ed.), Approaches to Primate Paleobiology: Basel (Kargel), 1-56.

Axelrod, D. I., and Raven, P. H., 1978. Late Cretaceous and Tertiary vegetation history. In Werger, M. (Ed.), Biogeography and Ecology of South Africa: The Hague (D. W. Junk), 77-130.

Baker, B. H., and Wohlenberg, J., 1971. Structure and evolution of the Kenya rift valley. Nature, 229:538-542.

Bandy, O. L., Casey, R. E., and Wright, R. C., 1971. Late Neogene planktonic zonation magnetic reversals, and radiometric dates, antarctic to tropics. Antarct. Res. Ser., 15:1-26.

Barnola, J. M., Raynaud, D., Korotkevich, Y. S., and Lorius, C., 1987. Vostok ice core provides 160,000-year record of atmospheric $\mathrm{CO}_{2}$. Nature, 329:408-414.

Barron, E. J., and Washington, W. M., 1985. Warm Cretaceous climates: high atmospheric $\mathrm{CO}_{2}$ as a plausible mechanism. In Sundquist, E. T., and Broecker, W. S. (Eds.), The Carbon Cycle and Atmospheric $\mathrm{CO}_{2}:$ Natural Variations Archean to Present: Washington (American Geophysical Union). Geophys. Monogr. Ser., 32:546-553.

Barron, E. J., Harrison, C.G.A., Sloan, J. L., III, and Hay, W. W., 1981. Paleogeography: 180 million years ago to the present. Eclogae Geol. Helv., 74:443-470.

Benjamin, M. T., Johnson, N. M., and Naeser, C. W., 1987. Recent rapid uplift in the Bolivian Andes: evidence from fission-track dating. Geology, 15:680-683.

Berger, A. L., 1978. Long-term variations of caloric solar radiation resulting from the earth's orbital elements. Quat. Res., 9:139-167.

Berner, R. A., Lasaga, A. C., and Garrels, R. M., 1983. The carbonate-silicate geochemical cycle and its effect on atmospheric carbon dioxide over the past 100 million years. Am. J. Sci., 283:641-683.

Berry, E., 1938. Tertiary flora from the Rio Pichileufu, Argentina. Spec. Pap., Geol. Soc. Am., 12:1-140.

Bonnefille, R., 1983. Evidence for a cooler and drier climate in the Ethiopian Highlands towards $2.5 \mathrm{Myr}$ ago. Nature, 303:487-491. 1984. Cenozoic vegetation and environments of early hominids in East Africa. In Whyte, R. O. (Ed.), The Evolution of the East Asian Environment (Vol. II): Hong Kong (Univ. of Hong Kong), 579-612.

1985. Evolution of the continental vegetation: the paleobotanical record from East Africa. S. Afr. J. Sci., 81:267-270.

Bornhold, B. D., 1983. Ice-rafted debris in sediments from Leg 71, southwest Atlantic Ocean. In Ludwig, W. J., Krasheninnikov, V. A., et al., Init. Repts. DSDP, 71, Pt. 1: Washington, D.C. (U.S. Govt. Printing Office), 307-316.

Boyle, E. A., and Keigwin, L. D., 1985. Comparison of Atlantic and Pacific paleochemical records for the last 215,000 years: changes in deep ocean circulation and chemical inventories. Earth Planet. Sci. Lett., 76:135-150. 
Broccoli, S., and Manabe, A. L., 1987. The influence of continental ice, atmospheric $\mathrm{CO}_{2}$, and land albedo on the climate of the last glacial maximum. Clim. Dyn., 1:87-99.

Burpee, R. W., 1972. The origin and structure of easterly waves in the lower troposphere of North Africa. J. Atmos. Sci., 29:77-90.

Butzer, K., 1957. The recent climatic fluctuation in lower latitudes and the general circulation of the Pleistocene. Geogr. Ann., 39:105-113.

Butzer, K. W., Issac, G. L., Richardson, J. L., and WashbournKamau, C., 1972. Radiocarbon dating of East African lake levels. Science, 175:1069-1076.

Caratini, C., Bellet, J., and Tissot, C., 1979. Etude microscopique de la matiere organique: palynologie et palynofacies. In Arnould, M., and Pelet, R. (Eds.), La géochemie organique des sédiments marins profonds: mission ORGON III (Mauritanie, Sénégal, Iles du Cap Vert): Paris (CNRS), 215-247.

Carlson, T. N., and Prospero, J. M., 1972. The large-scale movement of Saharan air outbreaks over the north equatorial Atlantic. $J$. Appl. Meteorol., 11:283-297.

Cerling, T. E., Bowman, J. R., and O'Neil, J. R., 1986. An isotopic study of a fluvial-lacustrine sequence: the Plio-Pleistocene Koobi Fora Sequence, East Africa. Palaeogeogr., Palaeoclimatol., Palaeoecol., 63:335-356.

Cieselski, P. F., and Grinstead, G. P., 1986. Pleistocene variations in the position of the antarctic convergence in the southwest Atlantic. Paleoceanography, 1:197-232.

Cieselski, P. F., and Weaver, F. M., 1974. Early Pliocene temperature changes in the Antarctic Seas. Geology, 2:511-515.

CLIMAP Project Members, 1981. Seasonal reconstruction of the earth's surface at the last glacial maximum. Map Chart Ser., Geol. Soc. Am., MC-36.

Coppens, Y., and Koeniguer, J. C., 1976. Paleoflores ligneuses tertiaire et quaternaire du Tchad. Palaeoecol. Afr., 9:105-106.

Curry, W. B., and Lohman, G. P., 1986. Late Quaternary carbonate sedimentation at the Sierra Leone Rise (eastern equatorial Atlantic Ocean). Mar. Geol., 70:223-250.

D'Almeida, G. A., 1986. A model for Saharan dust transport. J. Clim. Appl. Meteorol., 25:903-916.

Dean, W. E., Hay, W. W., and Sibuet, J.-C., 1984. Geologic evolution, sedimentation, and paleoenvironments of the Angola Basin and adjacent Walvis Ridge: synthesis of results of Deep Sea Drilling Project Leg 75. In Hay, W. W., Sibuet, J.-C., et al., Init. Repts. DSDP, 75, Pt. 1: Washington (U.S. Govt. Printing Office), 509-544.

Diester-Haass, L., 1983. Differentiation of high oceanic fertility in marine sediments caused by coastal upwelling and/or river discharge off northwest Africa during the late Quaternary. In Thiede, J., and Suess, E. (Eds.), Coastal Upwelling: The Sediment Record (Pt. B): New York (Plenum Press), 399-419.

Dubief, J., 1979. Review of the North African climate with particular emphasis on the production of eolian dust in the Sahel zone and in the Sahara. In Morales, C. (Ed.), Saharan Dust: Mobilization, Transport, Deposition: New York (Wiley), 27-48.

Einarsson, T., and Albertsson, K. J., 1988. The glacial history of Iceland during the past three million years. Phil. Trans. R. Soc. London, Ser. B, 318:637-644.

Flohn, H., and Nicholson, S. E., 1980. Climatic fluctuations in the arid belt of the "Old World" since the last glacial maximum: possible causes and future implications. Palaeoecol. Africa, $12: 3-22$.

Gardner, J. V., 1975. Late Pleistocene carbonate dissolution cycles in the eastern equatorial Atlantic. In Sliter, W. V., Bé, A.W.H., and Berger, W. H. (Eds.), Dissolution of Deep-Sea Carbonates. Spec. Publ., Cushman Found. Foraminiferal Res., 13:129-141.

Gardner, J. V., and Hays, J. D., 1976. Response of the sea-surface temperature and circulation to global climatic change during the past 200,000 years in the eastern equatorial Atlantic Ocean. In Cline, R. M., and Hays, J. D. (Eds.), Investigation of Late Quaternary Paleoceanography and Paleoclimatology. Mem. Geol. Soc. Am., 145:221-247.

Gates, W. L., 1976. The numerical simulation of ice-age climate with a global general circulation model. J. Atmos. Sci., 33:1138-1144.

Glaccum, R. A., and Prospero, J. M., 1980. Saharan aerosols over the tropical North Atlantic-mineralogy. Mar. Geol., 37:295-321.
Griffiths, J. F., 1972. Climates of Africa: Amsterdam (Elsevier).

Hastenrath, S., 1985. Climate and Circulation of the Tropics: Hingham, MA (D. Reidel).

Hayes, D. E., and Frakes, L. A., 1975. General synthesis, Deep Sea Drilling Project Leg 28. In Hayes, D. E., Frakes, L. A., et al., Init. Repts. DSDP, 28: Washington (U.S. Govt. Printing Office), 919-942.

Hays, J. D., 1965. Radiolaria and late Tertiary and Quaternary history of Antarctic Seas. Antarct. Res. Ser., 5:125-184.

Hays, J. D., and Opdyke, N. D., 1967. Antarctic radiolaria, magnetic reversals, and climatic change. Science, 158:1001-1011.

Hays, J. D., Imbrie, J., and Shackleton, N. J., 1976. Variations in the earth's orbit: pacemaker of the ice ages. Science, 194:1121-1132.

Hooghiemstra, H., 1988. Palynological records from northwest African marine sediments: a general outline of the interpretation of the pollen signal. Phil. Trans. R. Soc. London, Ser. B, 318:431-449.

Hooghiemstra, H., Bechler, A., and Beug, H.-J., 1987. Isopollen maps for 18,000 years B.P. of the Atlantic offshore of northwest Africa: evidence for paleowind circulation. Paleoceanography, 2:561-582.

Janecek, T. R., 1985. Eolian sedimentation in the northwest Pacific Ocean: a preliminary examination of the data from Deep Sea Drilling Project Sites 576 and 578. In Heath, G. R., Burckle, L. H., et al., Init. Repts. DSDP, 86: Washington (U.S. Govt. Printing Office), 589-603.

Jansen, E., Sjoholm, J., Bleil, U., and Erichsen, J. A., in press. Neogene and Pleistocene glaciations in the Northern Hemisphere and Miocene-Pliocene global ice volume fluctuations: evidence from the Norwegian Sea. In Bleil, U., and Thiede, J. (Eds.), Geologic History of the Polar Oceans: Arctic versus Antarctic: Dordrecht (Kluwer Acad. Publ.).

Kalu, A. E., 1979. The African dust plume: its characteristics and propagation across West Africa in winter. In Morales, C. (Ed.), Saharan Dust: Mobilization, Transport, Deposition: New York (Wiley), 95-118.

Keany, J., 1978. Paleoclimatic trends in the early and middle Pliocene deep-sea sediments of the Antarctic. Mar. Micropaleontol., 3:35-49.

Keany, J., and Kennett, J. P., 1972. Pliocene-early Pleistocene paleoclimatic history recorded in antarctic-subantarctic deep-sea cores. Deep-Sea Res., 19:529-548.

Keigwin, L. D., 1982. Isotopic paleoceanography of the Caribbean and east Pacific: role of Panama uplift in late Neogene time. Science, 217:350-353.

1986. Pliocene stable-isotope record of Deep Sea Drilling Project Site 606: sequential events of ${ }^{18} \mathrm{O}$ enrichment beginning at 3.1 Ma. In Ruddiman, W. F., Kidd, R. B., Thomas, E., et al., Init. Repts. DSDP, 94, Pt. 2: Washington (U.S. Govt. Printing Office), 911-920.

Kennett, J. P., 1970. Pleistocene paleoclimates and foraminiferal biostratigraphy in subantarctic deep-sea cores. Deep-Sea Res., 17:125-140.

1977. Cenozoic evolution of antarctic glaciation, the circum-Antarctic Ocean, and their impact on global paleoceanography, J. Geophys. Res., 82:3843-3860.

Kennett, J. P., and Vella, P., 1975. Late Cenozoic planktonic foraminifera and paleoceanography at DSDP Site 284 in the cool subtropical South Pacific. In Kennett, J. P., Houtz, R. E., et al., Init. Repts. DSDP, 29: Washington (U.S. Govt. Printing Office), 769-797.

Kidd, R. B., Cita, M. B., and Ryan, W.B.F., 1978. Stratigraphy of eastern Mediterranean sapropel sequences recovered during DSDP Leg $42 \mathrm{~A}$ and their paleoenvironmental significance. In Ryan, W.B.F., Cita, M. B., et al., Init. Repts. DSDP, 42: Washington (U.S. Govt. Printing Office), 421-443.

King, L. C., 1962. The Morphology of the Earth: New York (Hafner Publ.).

Kutzbach, J. E., 1981. Monsoon climate of the early Holocene: climatic experiment using the earth's orbital parameters for 9,000 years ago. Science, 214:59-61.

Kutzbach, J. E., and Gallimore, R. G., 1988. Sensitivity of a coupled atmosphere/mixed layer ocean model to changes in orbital forcing at 9,000 years B.P. J. Geophys. Res., 93:803-821.

Kutzbach, J. E., and Guetter, P. L., 1986. The influence of changing orbital boundary parameters and surface conditions on climate 
simulations for the past 18,000 years. J. Atmos. Sci., 39:17261759.

Kutzbach, J. E., Guetter, P. L., Ruddiman, W. F., and Prell, W. L., in press. The sensitivity of climate to late Cenozoic uplift in southern Asia and the American West: numerical experiments. $J$. Geophys. Res.

Kutzbach, J. E., and Street-Perrott, F. A., 1985. Milankovitch forcing of fluctuations in the level of tropical lakes from 18 to $0 \mathrm{kyr} \mathrm{BP}$. Nature, 317:130-134.

Labracherie, M., 1980. Les radiolaires temoins de l'evolution hydrologique depuis le dernier maximum glaciaire au large de Cap Blanc (Afrique du Nord-Ouest). Palaeogeogr., Palaeoclimatol., Palaeoecol., 32:163-184.

Lamb, P. J., Peppler, R. A., and Hastenrath, S., 1986. Interannual variability in the tropical Atlantic. Nature, 322:238-240.

Leinen, M., and Heath, G. R., 1981. Sedimentary indicators of atmospheric circulation in the Northern Hemisphere during the Cenozoic. Palaeogeogr., Palaeclimatol., Palaeoecol., 36:1-21.

Lezine, A., 1988. New pollen data from the Sahel, Senegal. Rev. Paleobot. Palynol., 55:141-154.

McDonald, W. F., 1938. Atlas of Climatic Charts of the Oceans: Washington (Dept. of Agriculture, Weather Bureau).

McIntyre, A., Ruddiman, W. F., Karlin, K., and Mix, A. C., 1989. Surface water response of the equatorial Atlantic Ocean to orbital forcing. Paleoceanography, 4:19-55.

Maier-Reimer, E., Crowley, T. J., and Mikolajewicz, U., 1989. Ocean GCM experiments with an open central American Isthmus. Am. Geophys. Union, Annu. Meet. Abstr., 70:367.

Maley, J., 1973. Mecanismes des changements climatiques aux basses latitudes. Palaeogeogr., Palaeoclimatol., Palaeoecol., 14:193-227. 1980. Les changements climatiques de la fin du Tertiaire en Afrique: leur consequence sur l'apparition du Sahara et de sa végétation. In Williams, M.A.J., and Faure, H. (Eds.), The Sahara and the Nile: Rotterdam (A. A. Balkema), 63-86.

, 1983. Histoire de la végétation et du climate de l'Afrique nord-tropicale au Quaternaire récent. Bothalia, 14:377-389.

Manabe, S., and Broccoli, A. J., 1985. The influence of continental ice sheets on the climate of an ice age. J. Geophys. Res., 90:2167-2190.

Manabe, S., and Hahn, D. G., 1977. Simulation of the tropical climate of an ice-age. J. Geophys. Res., 82:3889-8911.

Mead, G. A., Hodell, D. A., and Cieselski, P. F., 1988. Southern Ocean response to the onset of Northern Hemisphere glaciation at $2.4 \mathrm{Ma}$. Geol. Soc. Am., Abstr. Annu. Meet., p. A252.

Mercier, J.-L., Armijo, R., Tapponier, P., Carey-Gailhardis, E., and Lin, H. T., 1987. Change from late Tertiary compression to Quaternary extension in southern Tibet during the India-Asia collision. Tectonics, 6:275-304.

Milankovitch, M. M., 1941. Canon of Insolation and the Ice-Age Problem: Beograd (Koniglich Serbische Acad.).

Mix, A. C., in press. Pleistocene productivity: evidence from organic carbon and foraminiferal species. In Berger, W. H., Smetacek, V. S., and Wefer, G. (Eds.), Productivity of the Ocean: Present and Past: New York (Wiley).

Mix, A. C., Ruddiman, W. F., and McIntyre, A., 1986. Late Quaternary paleoceanography of the tropical Atlantic, 1: spatial variability of annual mean sea-surface temperatures, $0-20,000$ years B.P. Paleoceanography, 1:43-66.

Müller, P. J., and Suess, E., 1979. Productivity, sedimentation rate and sedimentary organic matter in the oceans. Part I, Organic carbon preservation. Deep-Sea Res., Pt. A, 26:1347-1362.

Nicholson, S. E., and Flohn, H., 1980. African environmental and climatic changes and the general atmosphere circulation in the late Pleistocene and Holocene. Clim. Change, 2:313-348.

Palmer, T. N., 1986. Influence of the Atlantic, Pacific, and Indian oceans on Sahel rainfall. Nature, 322:251-253.

Parkin, D. W., and Padgham, R. C., 1975. Further studies on trade winds during the glacial cycles. Proc. Trans. R. Soc. London, Ser. A, 346:245-260.

Parkin, D. W., and Shackleton, N. J., 1973. Trade wind and temperature correlations down a deep-sea core off the Saharan coast. Nature, 245:455-457.

Pastouret, L., Chamley, H., Delibrias, G., Duplessy, J. C., and Thiede, J., 1978. Late Quaternary climatic changes in western tropical Africa deduced from deep-sea sedimentation off the Niger delta. Oceanol. Acta, 1:217-232.

Petit-Maire, N., 1980. Holocene biogeographical variations along the northwestern African coast $\left(28^{\circ} \mathrm{N}-19^{\circ} \mathrm{N}\right)$ : paleoclimatic indications. Palaeoecol. Africa, 12:365-377.

Pflaumann, U., 1986. Sea-surface temperatures during the last 750,000 years in the eastern equatorial Atlantic: planktonic foraminiferal record of "Meteor"-cores 13519, 13521, and 16415. Meteor Forschungsergeb., Reihe C, 40:137-161.

in press. Temperaturreaktionen des nordaquatorialen Atlantiks auf globale klima-anfachung wahrend der letzten 750,000 Jahre. Paläoklimaforsch. Akad. Wiss. Literat. Mainz.

Pokras, E. M., 1987. Diatom record of late Quaternary climatic change in the eastern equatorial Atlantic and tropical Africa. Paleoceanography, 2:273-286.

Pokras, E. M., and Mix, A. C., 1985. Eolian evidence for spatial variability of late Quaternary climates in tropical Africa. Quat. Res., 24:137-149.

1987. Earth's precession cycle and Quaternary climatic change in tropical Africa. Nature, 326:486-487.

Prell, W. L., and Kutzbach, J. E., 1987. Monsoon variability over the past 150,000 years. J. Geophys. Res., 92:8411-8425.

Prell, W. L., and Van Campo, E., 1986. Coherent response of Arabian Sea upwelling and pollen transport to late Quaternary monsoonal sediments. Nature, 323:526-528.

Prospero, J. M., 1981. Arid regions as sources of mineral aerosols in the marine environment. In Pewe, T. L. (Ed.), Desert Dust: Origin, Characteristics, and Effects on Man. Spec. Pap., Geol. Soc. Am., 186:71-86.

Prospero, J. M., and Carlson, T. N., 1972. Vertical and aerial distribution of Saharan dust over the western equatorial North Atlantic Ocean. J. Geophys. Res., 77:5255-5265.

Pye, K., 1987. Aeolian Dust and Dust Deposits: New York (Academic Press).

Quezel, P., 1978. Analysis of the flora of Mediterranean and Saharan Africa. Ann. Mo. Bot. Gard., 65:479-534.

Raymo, M. E., Ruddiman, W. F., Backman, J., Clement, B. M., and Martinson, D. G., 1989. Late Pliocene variation in Northern Hemisphere ice sheets and North Atlantic deep circulation. $\mathrm{Pa}$ leoceanography, 4:413-446.

Rind, D., 1987. Components of the ice-age circulation. J. Geophys. Res., 92:4241-4281.

Rind, D., Peteet, D., Broecker, W. S., McIntyre, A., and Ruddiman, W. F., 1986. The impact of cold North Atlantic sea surface temperatures on climate: implications for the Younger Dryas cooling (11-10 K). Clim. Dyn., 1:3-34.

Ritchie, J. C., Eyles, C. H., and Haynes, C. V., 1985. Sediment and pollen evidence for an early to mid-Holocene humid period in the eastern Sahara. Nature, 314:352-355.

Rognon, P., 1980. Pluvial and arid phases in the Sahara: the role of non-climatic factors. Palaeoecol. Africa, 12:45-62.

Rognon, P., and Williams, M.A.J., 1977. Late Quaternary climatic changes in Australia and North Africa: a preliminary interpretation. Palaeogeogr., Palaeoclimatol., Palaeoecol., 21:285-327.

Rossignol-Strick, M., 1983. African monsoons, an immediate climatic response to orbital insolation. Nature, 303:46-49.

Rossignol-Strick, M., and Duzer, D., 1979. Late Quaternary pollen and dinoflagellate cysts in marine cores off West Africa. Meteor Forschungsergeb., Ser. C, 30:1-14.

Ruddiman, W. F., and Kutzbach, J. E., in press. Forcing of late Cenozoic Northern Hemisphere climate by plateau uplift in Southern Asia and the American West. J. Geophys. Res.

Ruddiman, W. F., and McIntyre, A., 1984. Ice-age thermal response and climatic role of the surface Atlantic Ocean, $40^{\circ} \mathrm{N}$ to $63^{\circ} \mathrm{N}$. Geol. Soc. Am. Bull., 95:381-396.

Ruddiman, W. F., Prell, W. L., and Raymo, M. E., in press. History of late Cenozoic uplift in Southern Asia and the American Southwest: rationale for general circulation modeling experiments. $J$. Geophys. Res.

Ruddiman, W. F., and Raymo, M. E., 1988. Northern Hemisphere climate regimes during the past $3 \mathrm{Ma}$ : possible tectonic connections. In Shackleton, N. J., West, R. G., and Bowen, D. Q. (Eds.), The Past Three Million Years: Evolution of Climatic 
Variability in the North Atlantic Region: Cambridge (Cambridge Univ. Press), 227-234.

Ruddiman, W. F., Raymo, M. E., and McIntyre, A., 1986. Matuyama 41,000-yr cycles: North Atlantic Ocean and Northern Hemisphere sheets. Earth Planet. Sci. Lett., 80:117-129.

Ryan, W.B.F., Hsü, K. J., et al., 1973. Init. Repts. DSDP, 13: Washington (U.S. Govt. Printing Office).

Sarnthein, M., 1978. Sand deserts during glacial maximum and climatic optimum. Nature, 272:43-46.

1982. Zur fluktuation der subtropischen wustengurtel seit dem letzen Hochglacial vor 18,000 jahren: klimahinweise und modelle aus tiefseesedimenten. Geomethodica, 7:125-161.

Sarnthein, M., and Diester-Haass, L., 1977. Eolian sand turbidites. J. Sediment. Petrol., 47:868-890.

Sarnthein, M., Tetzlaff, G., Koopman, B., Wolter, K., and Pflaumann, U., 1981. Glacial and interglacial wind regimes over the eastern subtropical Atlantic and northwest Africa. Nature, 293:193-196.

Sarnthein, M., Thiede, J., Pflaumann, U., Erlenkeuser, H., Fütterer, D., Koopman, B., Lange, H., and Seibold, E., 1982. Atmospheric and oceanic circulation patterns off northwest Africa during the past 25 million years. In von Rad, U., Hinz, K., Sarnthein, M., and Seibold, E. (Eds.), Geology of the Northwest African Continental Margin: Berlin-Heidelberg-New York (Springer-Verlag), 545-603.

Sarnthein, M., Winn, K., Duplessy, J.-C., and Fontugne, M. R., 1988. Global variations of surface ocean productivity in low and mid latitudes: influence on $\mathrm{CO}_{2}$ reservoirs of the deep ocean and atmosphere during the last 21,000 years. Paleoceanography, 3:361-399.

Schlesinger, M. E., and Mitchell, J.F.B., 1987. Climate model simulations of the equilibrium response to increased carbon dioxide. Rev. Geophys., 25:760-798.

Schneider, S. H., and Thompson, S. L., 1979. Ice ages and orbital variations: some simple theory and modeling. Quat. Res., 12:188-203.

Sclater, J. G., Hellinger, S., and Tapscott, C., 1977. The paleobathymetry of the Atlantic Ocean from the Jurassic to the Recent. J. Geol., 85:509-522.

Seibold, E., 1980. Climate indicators in marine sediments off northwest Africa-a critical review. Palaeoecol. Africa, 12:175-187.

Shackleton, N. J., Backman, J., Zimmerman, H., Kent, D. V., Hall, M. A., Roberts, D. G., Schnitker, D., Baldauf, J., Desprairies, A., Homrighausen, R., Huddlestun, P., Keene, J. B., Kaltenback, A. J., Krumsiek, K.A.O., Morton, A. C., Murray, J. W., and Westberg-Smith, J., 1984. Oxygen isotope calibration of the onset of ice rafting: history of glaciation in the North Atlantic region. Nature, 307:620-623.

Shackleton, N. J., and Opdyke, N. D., 1976. Oxygen isotope and paleomagnetic stratigraphy of Pacific core V28-239: late Pliocene to latest Pleistocene. In Cline, R. M., and Hays, J. D. (Eds.), Investigations of Late Quaternary Paleoceanography and Paleoclimatology. Mem. Geol. Soc. Am., 145:449-464.

Stein, R., 1985a. Late Neogene changes of paleoclimate and paleoproductivity off northwest Africa (DSDP Site 397). Palaeogeogr., Palaeoclimatol., Palaeoecol., 49:47-59. 1985b. The post-Eocene sediment record of DSDP Site 366 implications for African climate and plate tectonic drift. Mem. Geol. Soc. Am., 163:305-315.

1986. Late Neogene evolution of paleoclimate and paleoceanic circulation in the Northern and Southern Hemispheres-a comparison. Geol. Rundsch., 75:125-138.

Stein, R., and Sarnthein, M., 1984. Late Neogene events of atmospheric and oceanic circulation patterns offshore northwest Africa: high-resolution record from deep-sea sediments. Palaeoecol. Afr., 16:9-36.

Street, F. A., and Grove, A. T., 1976. Environmental and climatic implications of late Quaternary lake level fluctuations in Africa. Nature, 261:385-390.

Street-Perrott, F. A., and Harrison, S. P., 1984. Temporal variations in lake levels since 30,000 yr BP-an index of the global hydrological cycle. In Hansen, J. E., and Takahashi, T. (Eds.), Climate Processes and Sensitivity: Washington (American Geophysical Union). Geophys. Monogr. Ser., 29:118-129.

Suc, J.-P., 1984. Origin and evolution of the Mediterranean vegetation and climate in Europe. Nature, 307:429-432.

Tetzlaff, G., Peters, N., Janssen, W., and Adams, L. J., in press. Aeolian dust transport in West Africa. In Leinen, M., and Sarnthein, M. (Eds.), Paleoclimatology and Paleometeorology: Modern and Past Patterns of Global Atmospheric Transport: Dordrecht (Kluwer Acad. Publ.).

Thiede, J., 1977. Aspects of the variability of the glacial and interglacial North Atlantic eastern boundary current (last 150,000 years) Meteor Forschungsergeb., Reihe C, 28:1-36.

Thunell, R. C., and Belyea, P., 1982. Neogene planktonic foraminiferal biogeography of the Atlantic Ocean. Micropaleontology, 28:381-398.

Thunell, R. C., Williams, D. G., and Belyea, P. C., 1984. Anoxic events in the Mediterranean Sea in relation to the evolution of late Neogene climate. Mar. Geol., 59:105-134.

Thunell, R. C., Williams, D. F., and Howell, M., 1987. AtlanticMediterranean water exchange during the late Neogene. Paleoceanography, 2:661-678.

Traverse, A., 1982. Response of world vegetation to Neogene tectonics and climatic events. Alcheringia, 6:197-209.

van Zinderen Bakker, E. M., and Mercer, J. H., 1986. Major late Cainozoic climatic events and palaeoenvironmental changes in Africa viewed in a world wide context. Palaeogeogr., Palaeoclimatol., Palaeoecol., 56:217-235.

Vrba, E. S., 1985. African Bovidae: evolutionary events since the Miocene. S. Afr. J. Sci., 81:263-266.

Wesselman, H. B., 1985. Fossil micromammals as indicators of climatic change about 2.4 m.y. ago in the Omo Valley, Ethiopia. $S$. Afr. J. Sci., 81:260-261.

Wijmstra, T. A., and Groenhart, M. C., 1983. Record of 700,000 years vegetational history in eastern Macedonia (Greece). Rev. Acad. Colomb. Cienc. Exactas, Fis. Nat., 15:87-98.

Date of initial receipt: 14 February 1989

Date of acceptance: 18 May 1989

Ms 108B-173 